\title{
Solar Photovoltaics Contribution To Energy Mix In Selected Nigerian Estates
}

\author{
Adeyemi Adepoju \\ Federal University of Technology, Akure, \\ Department of Project Management Technology, Akure \\ Olalekan Jesuleye \\ Federal University of Technology, Akure, \\ Department of Project Management Technology, Akure, Nigeria \\ Olutosin Arigbede \\ Federal University of Technology, Akure, \\ Department of Project Management Technology, Akure, Nigeria
}

\begin{abstract}
This paper assessed the share of Solar Photovoltaics (PV) in the energy mix for various energy services in Nigerian residential estate. Model for Analysis of Energy Demand (MADE-II) was used to analyze the primary and other secondary data obtained for the study. The results showed that the current contribution of solar PV in energy demand split for the estates was still low, with a total share of $8.8 \%, 6.7 \%$ and $4.4 \%$ in Ijapo, Alagbaka and Sunshine Housing Estate despite various government interventions. Its usage level constituted an insignificant share of $27.9 \%, 57.3 \%, 18.3 \%, 0 \%, 0 \%, 0 \%, 0 \%$, and $16.8 \%$ for the total lighting, computing/internet, entertainment, process heat, cooking, refrigeration, water pumping and ventilation services requirement respectively in Ijapo Housing Estate, 26.5\%, 70.6\%, 13.7\%, 0\%, 0\%, 0\%, 0\%, and 16.5\% in Alagbaka Housing Estate, and $24.0 \%, 50 \%, 14.1 \%, 0 \%, 0 \%, 0 \%, 0 \%$, and $1.8 \%$ in Sunshine Housing Estate. The study concluded that utilization of solar PV as an energy source for energy service ensure access to affordable, reliable, sustainable and modern energy for all. The research recommended that government support for solar PV intervention should be further encouraged.
\end{abstract}

Keywords: Solar Photovoltaic, Energy services, Renewable energy, Sustainable development

\section{INTRODUCTION}

Globally, the utilization of Solar Photovoltaic (PV) among residential is attracting more researchers' interests in the recent times. This was influenced by a call to action made in 2015 at the United Nations Summit for Sustainable Development for a much wider and greater access to affordable, reliable and sustainable energy as a prerequisite for eradicating poverty by 2030 [1]. World leaders affirm this in 2016 at their summit with a global consensus that: the Sustainable Development Goals (SDGs) is not achievable without efficient energy access to increase production, income, create jobs and reduce drudgery [2]. The importance of access to energy in facilitating economic development, reducing poverty, broadening the reach of education and improving health has been well explored $[3,4,5, \& 6]$.

Nigeria is the most populous black nation on earth, but $47 \%$ of its current population of about 200 million lack access to electricity [7]. The primary inhibiting factors to electricity generations, transmissions, and distributions have to do with geographic remoteness, cost of transmission, and inadequate government commitments [7]. According to Jesuleye (2010) [8], it is important that strategies for electrification be renewable energy sources because Africa is 
extremely vulnerable to climate change and the continent has more solar radiation than any other continent on earth. Renewable Energy Master Plan (REMP) drafted in 2005, reveals Nigeria's Plans to supply $18 \%$ of its electricity from solar energy by 2020 [9].

The most pursue renewable energy source is solar photovoltaics (PV) because it is environmentally and weather friendly, low maintenance, possibility of expandability, it requires no fuel, it has no pollution, and it also has no noise. This system works by converting sunlight into electrical power. It is achieved by using a thin layer of semi-conducting material, normally silicon, concealed in a plastic casing or glass. They could have different sizes ranging from small versions used to power-on wrist watches to a system of hundreds of square meters of solar PV panels integrated to power small or large buildings. It is one of the cleanest forms of energy as it doesn't release emissions to the environment and its source is inexhaustible. The potential for electricity generation from solar energy is enormous.

Nigeria has had its own share of the impacts of climate change. This effect can be seen in the constant erosion and flooding of the Niger-Delta region of the country, the desertification of the northern region and the drying up of Lake Chad. If actions are not taken to combat climate change, the cost of adaptation will certainly be more than the cost of mitigation. For instance, the post disaster assessment of the 2012 flood in Nigeria estimated the amount of damage caused to be around US $\$ 17$ billion (Nkwunonwo, 2016). This amount is 2 percent of the real GDP in that year.

The mitigation of dangerous anthropogenic climate change is seen as one strong driving force behind the increased use of renewable energy such as wind, solar, hydro and biomass [10]. Renewable energy offers the opportunity to contribute to a number of important sustainable development goals among which are: social and economic development, energy access, energy security, climate change mitigation and the reduction of environmental and health problems [1].

According to Onasanya (2017) [11], Household energy consumption accounts largely for climate change. Energy conversion from traditional sources in households will play a major role in the mitigation of climate change and its effects. Electricity consumption is an important and large part of household energy consumption, therefore its production from a sustainable source will be hugely significant in combating the present climate change issues.

Nigeria consumers of electricity could be classified into three major groups which include: The industrial sector; the commercial sector and street lighting and the residential sector. Residential sector is by far the largest electricity consumer in Nigeria, followed by the commercial sector and street lighting then the industrial sector [8]. This however highlights the importance of sustainable residential energy use in the quest for curbing climate change.

One of such communities is Akure, the capital city of Ondo State in South-western Nigeria. The State is nicknamed "sunshine state" because of its equatorial location and the climatic condition, solar radiation is appreciable for a good part of the year. There are two distinct seasons: the rainy season which starts in April and peaks in June through September and the dry season which begins in November and lasts till April [12]. It is an agrarian and educational centre situated in the central part of the State. Akure is a medium sized city with population of 360, 268 people according to the 2006 National Population and Housing Census. It is home to the best university of Technology in Nigeria; Federal University of Technology Akure, Akure [13]. It is located about $311 \mathrm{~km}$ North-east of Lagos, about $370 \mathrm{~m}$ above sea level. In addition, 
the State is an oil producing state, and has been classified as a Millennium Development City. All these factors collectively influence population growth of the city.

The three housing estates are located within the city at different areas. Ijapo Housing Estate is located within the peripheral zone of the city in close proximity to Oke Ijebu roundabout. It is a mixture of prototype-housing design and site-and-services. Alagbaka Housing Estate is also located in the peripheral zone of the city in close proximity to the Bishop's Court roundabout. It is a site-and-services estate where the residents purchased the land from the government in order to build by themselves while government provides the services. Conversely, Sunshine Housing Estate in located in a suburb of the Akure city called Oba-Ile. It is a prototype-housing estate built through Public-Private Partnership between the State government and a private developer, who built all the houses and provided the services, while the users purchased the already finished houses.

There is a need to investigate the status of the Solar PV system as well as the factors that could be influencing the use of solar PV for energy services. This is because appreciable number of Solar PV installation now exists in the communities. It has been documented in the industrialised countries that public acceptance of renewable energy technologies is crucial to their successful introduction into society [14]. This is because poor public acceptance of renewable energy technologies could hinder the implementation of sustainable energy technologies which hampers the attainment of important environmental and societal goals [15].

The article is divided into five sections. Section 1 introduces the article; section 2 presents the theoretical and empirical reviews as well as the status of Residential estates in Nigeria. Section 3 and 4 present the methodology used to carry out the study and results analyses respectively, while section 5 concludes the article.

\section{LITERATURE REVIEW}

This section provides the empirical reviews of the study as well as the status of residential Estates in Nigeria.

\section{Solar Power Usage In Residential Building}

In discussing solar usage in residential premises, two options that readily come to mind are application for thermal (when a heat pipe are arranged to heat up hot water) and solar home electricity. By comparison, the solar thermal is more efficient as regards storing and conserving of energy for future use. Also the largest draw on power use that most family have after running the refrigerator is hot water for showers and cleaning. A solar power residential system is a bit technical as necessary information may need to be taken on the actual electricity usage and the orientation of the house as the system requires a south facing solar panel system where sunlight can be trapped and converted to electricity [14]. This however depends on how the house was constructed as this may or may not be feasible as the more the radiation received during the day, the more efficient it is when the need arises. [14]

\section{Components Of Solar Pv Installation}

A typical photovoltaic solar PV system consists of four basic elements: Photovoltaic module, charge controller, the inverter and battery when necessary [16, $17 \& 18]$

\section{Solar PV Module}

This is commonly referred to as a solar panel. The photovoltaic module consists of photovoltaic cells, i.e., the surfaces that generate electricity, which convert directly solar energy into 
electricity. These surfaces have no moving parts to wear out or suffer breakdowns and works without the use of fuel without vibrations without noise and without harming the environment. It is responsible for trapping of solar energy as it is placed outside under the sun. They are arranged in series and parallel to meet desired output [16, 17 \& 18].

\section{Charge Controller}

A charge controller monitors the battery's state-of-charge to insure that when the battery needs charge current, it gets it and also ensures the battery isn't overcharged. Connecting a solar panel to a battery without a regulator seriously risks damaging the battery and potentially causing a safety concern $[16,17 \& 18]$.

\section{Inverter}

Required to convert the direct current (DC) power produced by the PV module into Alternating current (AC) power. Most solar power systems generate Dc current which is stored in batteries while nearly all lighting, appliances, motors and so on, are designed to use AC power, so it takes an inverter to make the switch from battery-stored DC to standard power (120VAC, $60 \mathrm{~Hz})[16,17 \& 18]$.

\section{Deep Cycle Battery:}

It stores electricity to provide energy on demand at night or on overcast days. They are designed to be discharged and then recharged hundreds or thousands of times. These batteries are rated in amp-hours, usually at 20 hours and 100 hours. Like solar panels, batteries are wired in series and/or parallel to increase the voltage to the desired level and increase amp hours. The recommended batteries that should be used in a stand-alone photovoltaic power system are deep-cycle lead-acid batteries because of their high performance [16, 17 \& 18].

Figure 2: Typical System of photovoltaic solar energy [16]

Consumption 12 volts DC

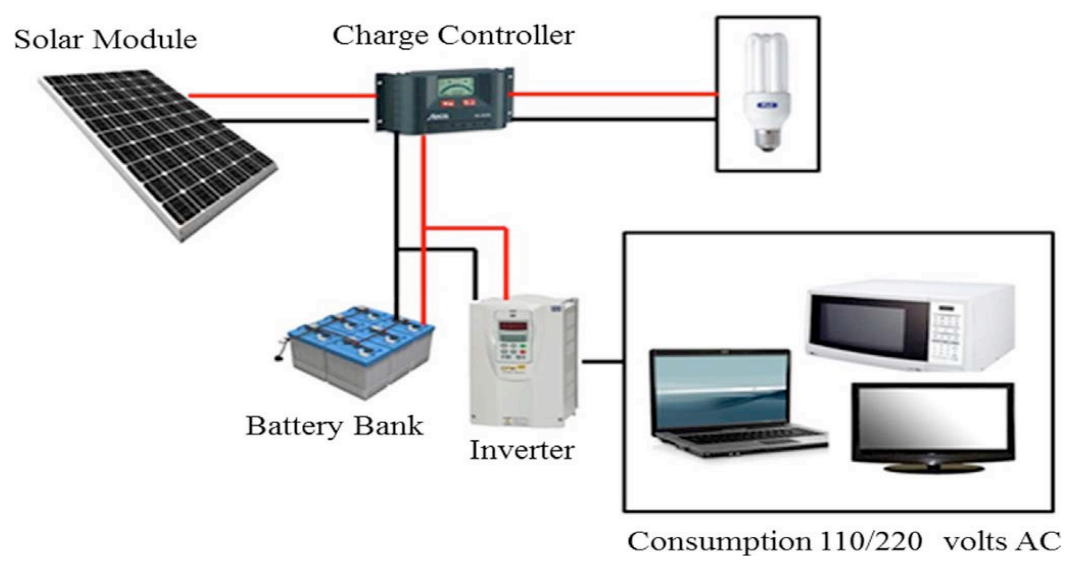

\section{Empirical Literature On Solar Pv Contribution To Energy Service}

Solar Photovoltaic market is a rapidly growing worldwide [19]. During the period between 2000 and 2015 the growth rate of photovoltaic installations was of $41 \%$. It is observed that China and Taiwan since 2006 have been increasing the photovoltaic industry with strong growth rates. At the end of 2015, its market share was about $71 \%$ of global sales. The market for photovoltaic systems will likely continue to grow in the future as strongly as so far, due to the thrust of subsidies, tax breaks and other financial incentives. Support for R \& D and photovoltaic technology change are crucial aspects in accelerating the widespread utilization of photovoltaic systems [19]. 
Europe contributed 40\% of total cumulative PV installations in 2015 (in 2014 it was 48\%). European countries such as Germany, Denmark and Spain, in addition to Asian countries China and Taiwan, have used feed-in tariff (FIT) which is a political mechanism to encourage consumers to invest in renewable microgeneration. On the other hand, the United States, United Kingdom, Japan and Sweden, have used the RPS (Renewable Portfolio Standard), which is a regulation that requires that part of the energy consumed comes from renewable sources.

The facilities in China and Taiwan accounted for 21\% of total cumulative installations (in 2014 was $17 \%$ ). In 2015, Germany accounted for about 16\% (39.6 GWp) of cumulative installed PV capacity worldwide (242 GWp). In 2015, the newly installed capacity in Germany was about 1.4 GWP; in 2014 it was $1.9 \mathrm{GWp}$. In total, 1.5 million photovoltaic systems were installed in Germany.

Jesuleye (2017) [20] analyzed the current status of Solar Photovoltaics (PV) for lighting in Danjiwa and Dahuwa remote villages that are pilot sites for rural electrification projects in Nigeria. Model for Analysis of Energy Demand (MADE-II) was used to analyze the primary and other secondary data obtained for the study. The results showed that the current contribution of solar PV in the lighting demand split for the villages was still very low in spite of various government interventions. Its usage level constituted an insignificant share of $16.4 \%$ and 5.5\% of the total lighting requirement for Danjiwa and Dahuwa villages respectively. For each village, lighting with incandescent bulbs was about $10 \%$ of this total requirement, while that of fluorescent lambs stood at $7 \%$ and 6.5 respectively. The research results also revealed that kerosene maintained a domineering share of $66 \%$ and $77 \%$ of the total demand in the two villages respectively.

Ismail, Ajide and Akingbesote (2012) [21], embarked on performance assessment of installed solar PV system in Oke agunla, Akure LG area of Ondo state in Nigeria, it was concluded that the PV systems were inefficient as a result of poor maintenance, lack of technical know-how and inability of the project contractors or managers to take these factors into consideration while embarking on the solar PV installations.

Melodi \& Famakin (2011) [22], in a study to determine the adequacy of solar electricity potential (SEP) for meeting the domestic demand of Akure, concluded that SEP in Akure is appreciable and sufficient as an alternative energy source for domestic needs.

\section{METHODOLOGY OF THE STUDY}

\section{Adaptation of Model for Analysis of Demand for Energy (MADE-II) for Data Analysis}

Model for Analysis of Demand Energy (with the acronyms MADE-II), developed at the Institute for Energy Economics and Rational use of Energy, University of Stuttgart, Germany in 1989, is the adapted energy demand analysis model for this paper. The Model combines the application of statistical, econometric and engineering process techniques as appropriate for the various sectors of the economy. As presented in Figure. 2.

MADE-II is made up of 7 blocks of data in flow for demand analysis. Block 1 deals with general information about energy levels, base year and future time periods while information on development of population is presented in Block 2. Data analysis for useful energy demand in the households sector is treated in Block 3, while block 4 and 5 deal with the Households, Cottage Industries and Community Services sectors. The transport sector is not included in the analysis while block 7 deals with efficiencies, penetration factors and sectoral demand for Solar Electricity Lighting. Other Energy Services such as: Water Pumping for Drinking and 
Irrigation Purposes, Powering of TV, Video, Radio, Refrigeration, Ventilation, Cooking and Process Heat are not considered in the analysis due to dearth of data.

The basic analytical approach employed in MADE-II which makes it suitable for demand analysis of solar electricity in Nigeria is its flexibility and applicability for demand projection over short or long period. So also, analytical techniques adopted in MADE-II rest on the idea that energy is a means to an end and it is used together with other production factors to provide products (in form of goods and services) to the society.

Figure. 2: Adapted Data Flow in MADE -II (Model for Analysis of Demand for Energy) (Jesuleye 2010)

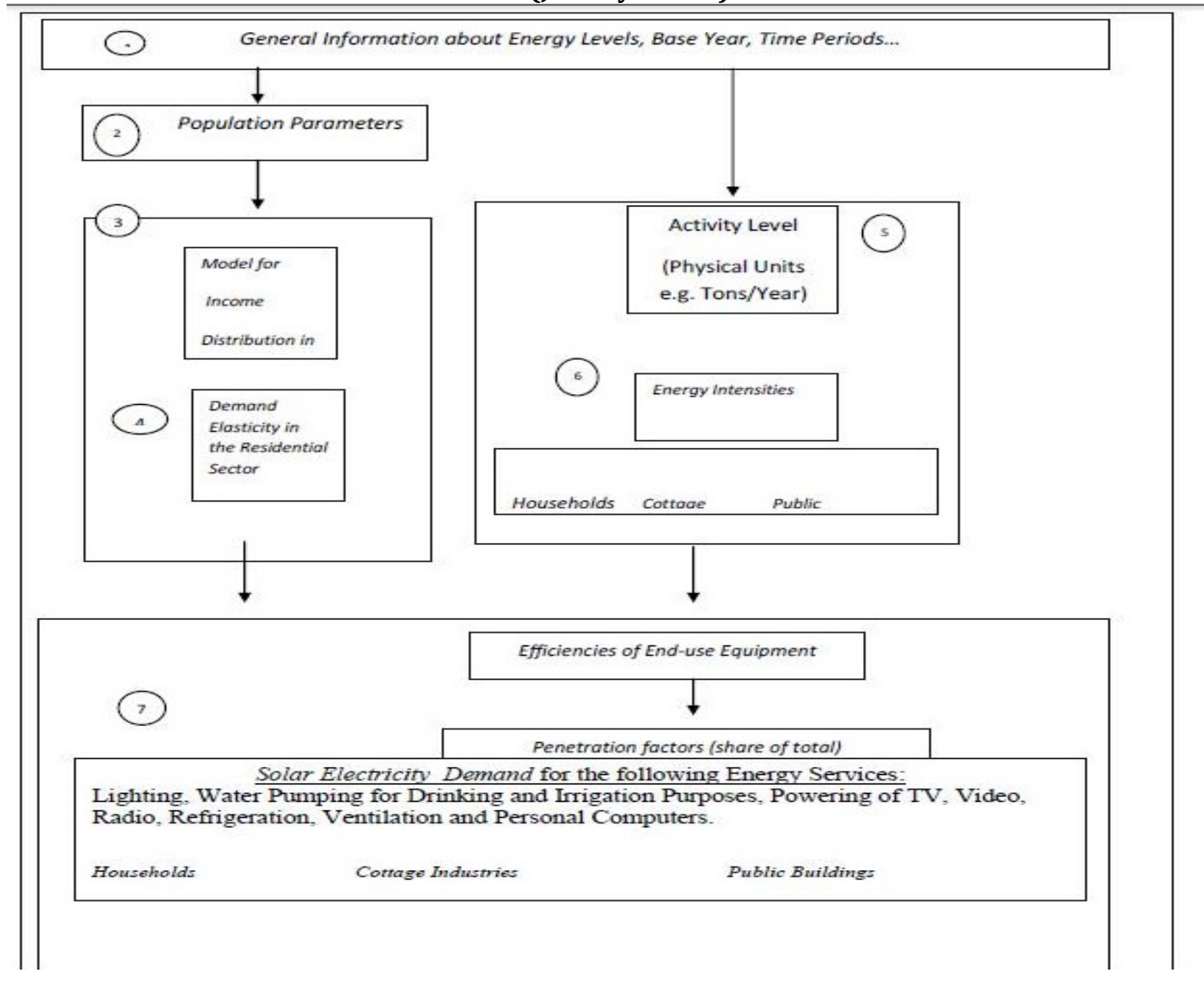

Measurement of Variables for energy services by Solar PV in Each Estate

Energy consumption data of each village in the study areas were used to quantify total demand for energy services. This involves the calculation of energy intensities as represented in the equation as below:

Energy Intensity $(E I j, t)=((D S E S j, t)$ Energy input $(W p)) /((A L j, t)$ Population Share (Million) $)$

Where,

DSESj.t $=$ ALj,t $*$ EIj,t

DSESj,t : Household demand D for Solar PV Services j (e.g. lighting) in time t. 
ALj,t : Household Activity Level (AL) (Population share) for solar PV service j (e.g lighting) in time period $t$.

EIj,t : Household Energy Intensity (EI) for Solar PV service j (e.g lighting) in time t.

Wp : Watt peak

\section{Adapted from Jesuleye (2010)}

\section{RESULTS \\ General Information and Profiles of Solar PV Installations in the Study Areas.}

Ijapo Housing Estate is located within the peripheral zone of the city near Oke Ijebu roundabout. It is a mixture of prototype-housing design and site-and-services. With a population of 3000, Table 1 shows a Profile of Solar PV installation in Ijapo. In Ijapo Housing Estate, the number of households Connected is 128, which makes $21.3 \%$ of the households. The most common application is solar home system installation and Solar Street light with a total capacity of 232KW which were installed between 2011 and 2019. The installation comprises of Solar Panel, Storage Battery, Inverter, Charge controllers and ELCB Breaker. The PV Installation is used as an alternative Energy source. The PV installations are Self-sponsored, and $58.6 \%$ of the respondents Stated that the PV system is working very well and last an average of 5-6 hours. The users are responsible for monitoring and sustainability.

Table 1 shows a summary/Profile of Solar PV installation in Ijapo Housing Estate.

\begin{tabular}{lll}
\hline S/N & Characteristics & Remark \\
\hline 1 & Estimated populations & 3000 \\
\hline 2 & Average number of household & 600 \\
\hline 3 & Average number of people per household & 5 \\
\hline 4 & Number of household Connected & 128 \\
\hline 5 & Percentage of house connected & $21.3 \%$ \\
\hline 6 & Type of solar installation & Solar Home system and solar street light \\
\hline 7 & Year of Installation of PV System & $2011-2019$ \\
\hline 8 & Total capacity of PV installed & $232 \mathrm{KW}$ \\
\hline 9 & Major Component of PV Installation & Solar Panel, Storage Battery, Inverter, \\
& & Charge controllers, ELCB Breaker \\
\hline 10 & Objective of the PV Installation & Alternative Energy source \\
\hline 11 & Sponsor of the PV installation & Self-sponsored \\
\hline 12 & Status of the installation & $58.6 \%$ working very well \\
\hline 13 & Average hours of usage & 6 \\
\hline 14 & Monitoring and sustainability & User \\
\hline
\end{tabular}

Researcher's Field Report (2019)

Alagbaka Housing Estate is also located in the peripheral zone of the city near the Bishop's Court roundabout. It is a site-and-services estate where the residents purchased the land from the government in order to build by themselves while the government provides the services. With a population of 1540, Table 2 shows a Profile of Solar PV installation in the study area. In Alagbaka Housing Estate, the number of household Connected is 59, which makes $19.2 \%$ of the households Estate. The most common application is solar home system installation with a Total capacity of 93KW which were installed between 2013 and 2018. The installation comprises of Solar Panel, Storage Battery, Inverter, Charge controllers and ELCB Breaker. The PV Installation is used as an alternative Energy source. The PV installations are Self-sponsored, and $54.2 \%$ of the respondents stated that the PV system is working very well and last an average of 5-6 hours. The users are responsible for monitoring and sustainability. 
Table 2 shows a summary/Profile of Solar PV installation in Alagbaka Housing Estate

\begin{tabular}{lll}
\hline S/N & Characteristics & Remark \\
\hline 1 & Estimated populations & 1540 \\
\hline 2 & Average number of household & 308 \\
\hline 3 & Average number of people per household & 5 \\
\hline 4 & Number of household Connected & 59 \\
\hline 5 & Percentage of house connected & $19.2 \%$ \\
\hline 6 & Type of solar installation & Solar Home system \\
\hline 7 & Year of Installation of PV System & $2013-2018$ \\
\hline 8 & Total capacity of PV installed & $93 \mathrm{KW}$ \\
\hline 9 & Major Component of PV Installation & Solar Panel, Storage Battery, Inverter, \\
& & Charge controllers, ELCB Breaker \\
\hline 10 & Objective of the PV Installation & Alternative Energy source \\
\hline 11 & Sponsor of the PV installation & Self-sponsored \\
\hline 12 & Status of the installation & $54.2 \%$ working very well \\
\hline 13 & Average hours of usage & 6 \\
\hline 14 & Monitoring and sustainability & User \\
\hline
\end{tabular}

Researcher's Field Report (2019)

Sunshine Housing Estate is located in a suburb of the Akure city called Oba-Ile. It is a prototype-housing estate built through Public-Private Partnership between the State government and a private developer, who built all the houses and provided the services, while the users purchased the already finished houses. With a population of 880, Table 3 presents a Profile of Solar PV installation in the study area. In Sunshine Gate Housing Estate, the number of household Connected is 32 , which makes $18.2 \%$ of the households in the Estate. The most common application is solar home system installation with a Total capacity of 39.5KW which were installed between 2012 and 2018. The installation comprises of Solar Panel, Storage Battery, Inverter, Charge controllers and ELCB Breaker. The PV Installation is used as an alternative Energy source. The PV installations are Self-sponsored, and $87.5 \%$ of the respondents Stated that the PV system is working very well and last an average of 5-6 hours. The users are responsible for monitoring and sustainability.

Table 3 shows a summary/Profile of Solar PV installation in Sunshine Housing Estate

\begin{tabular}{lll}
\hline S/N & Characteristics & Remark \\
\hline 1 & Estimated populations & 880 \\
\hline 2 & Average number of household & 176 \\
\hline 3 & Average number of people per household & 5 \\
\hline 4 & Number of household Connected & 32 \\
\hline 5 & Percentage of house connected & $18.2 \%$ \\
\hline 6 & Type of solar installation & Solar Home system \\
\hline 7 & Year of Installation of PV System & $2012-2018$ \\
\hline 8 & Total capacity of PV installed & $39.5 \mathrm{KW}$ \\
\hline 9 & Major Component of PV Installation & Solar Panel, Storage Battery, Inverter, \\
& & Charge controllers, ELCB Breaker \\
\hline 10 & Objective of the PV Installation & Alternative Energy source \\
\hline 11 & Sponsor of the PV installation & Self-sponsored \\
\hline 12 & Status of the installation & $87.5 \%$ working very well \\
\hline 13 & Average hours of usage & 6 \\
\hline 14 & Monitoring and sustainability & User
\end{tabular}

Researcher's Field Report (2019) 


\section{Data and Sample Population}

The population for this study comprises of Solar PV users in the three housing estates under study namely: Ijapo (IHE), Alagbaka Extension (AHEE) and Sunshine Gardens Housing Estates (SGHE). The number of housing units in IHE is 600, while for AHEE and SGHE are 308 and 176 respectively. This brings the total housing units for the study area to 1,084 buildings [23].

The sample size for solar PV users using Using Taro Yamane formula is;

$=1084 /(1+1084(0.0025))$

$$
n=N /(1+N(e) 2)
$$

$=292$ respondents

Using the bourleys formula this translates to sample sizes of 162, 83 and 47 for IHE, AHE and SHE respectively.

Sample size for Ijapo Housing Estate $=(600 \times 292) / 1084=162$ respondents

Sample size for Alagbaka Housing Estate $=(308 \times 292) / 1084=83$ respondents

Sample size for Sunshine Housing Estate $=(176 \times 292) / 1084=47$ respondents

\section{Data presentation and Analysis}

\section{DISCUSSION}

This chapter presents the statistical analysis results and discussion on the assessment of Solar Photovoltaic Utilization for energy services in selected estates in Akure, Ondo State. The response rate of the survey questionnaire collected was examined in line with the study of Cooper and Schindler (2007)[24], who explained that the collected raw data should be examined for correctness, accuracy and completeness. In this study, 300 copies of questionnaire were administered to respondents. 165 questionnaires were administered in Ijapo Housing Estate, and 128 were completed correctly and returned, representing a percentage response of 78\%. 85 was distributed in Alagbaka Housing Estate, and 59 were completed correctly and returned representing a percentage response of $69 \%$ while 50 was shared in Sunshine Housing Estate, and 32 were completed correctly and returned representing a percentage response of $64 \%$. A total of 219 were completed correctly and returned, representing a percentage response of $73 \%$, as shown in Table 4 . Mugenda and Mugenda (2003)[25], states that a response rate of 50\% is adequate for analysis and reporting; a rate of $60 \%$ is good, and a response rate of $70 \%$ and over is Excellent. Hence the response rate was satisfactory, as indicated in Table 4.

\section{Demographic Information of Respondents}

This section discussed the demographic information of the respondents in Ijapo Housing Estate. First, the researcher sought to establish the gender of the respondents. Their responses are shown in Table 4. In Ijapo Housing Estate (IHE), 84.4\% of the respondents are males, while 15.6\% are female. In Alagbaka Housing Estate (AHE), 81.4\% of the respondents are males, while 18.6\% are female. In Sunshine Housing Estate (SHE), all the respondents are males. Overall $85.8 \%$ of the household heads were males while as $14.2 \%$ of the household heads were females. This implies that there were more male respondents than females. This may be so because of the dominance

Table 4: Response Rate of Questionnaires Distributed and Retrieved

\begin{tabular}{lllll}
\hline Questionnaires & IHE & AHE & SHE & Total \\
\hline Number Distributed & 165 & 85 & 50 & 300 \\
Number Received and used & 128 & 59 & 32 & 219 \\
Percentage & $\mathbf{7 8 \%}$ & $\mathbf{6 9 \%}$ & $\mathbf{6 4 \%}$ & $\mathbf{7 3 \%}$ \\
\hline
\end{tabular}

Researcher's Field Report (2019) 
of male as head of household in Africa [26]. This, however, will not affect the responses from the respondents, thereby creating any form of biasness. Next, sought to establish the age of the household heads. Their responses are highlighted in Table 5. In Ijapo Housing Estate (IHE), None $(0 \%)$ of the respondents were aged below 20 years, $10.9 \%$ of the household heads were aged between 21 to 29 years, $48.4 \%$ of the household heads were aged between 31 to 39 years and $40.6 \%$ of the household heads were aged 40 years and above. In Alagbaka Housing Estate (AHE), None $(0 \%)$ of the respondents were aged below 20 years, and between 21 to 29 years, $76.3 \%$ of the household heads were aged between 31 to 39 years, and $23.7 \%$ of the household heads were aged 40 years and above. In Sunshine Housing Estate (SHE), None (0\%) of the respondents were aged below 20 years, and between 21 to 29 years, $57.5 \%$ of the household heads were aged between 31 to 39 years, and $36.1 \%$ of the household heads were aged 40 years and above. Overall None (0\%) of the respondents were aged below 20 years, $6.4 \%$ of the household heads were aged between 21 to 29 years, $57.5 \%$ of the household heads were aged between 31 to 39 years, and $36.1 \%$ of the household heads were aged 40 years and above. This shows that the largest population of respondents were young and matured enough; as a result, they were able to understand issues related to solar technology. Table 5 also reflect a compliment to their level of education as the study composition indicates clearly that in Ijapo Housing Estate (IHE), 71.1\% of the respondents have already earned a bachelor degree, while 6.3\%, 21.9\% and $0.8 \%$ are holders of HND, Masters and PhD Respectively. In Alagbaka Housing Estate (AHE), $86.4 \%$ of the respondents have already earned a bachelor degree, while $5.1 \%$ and $8.5 \%$ are holders of HND, Masters Respectively and none (0\%) are OND/Certificate and $\mathrm{PhD}$ holder. In Sunshine Housing Estate (SHE), 71.9.4\% of the respondents have already earned a bachelor degree, while $3.1 \%$ and $25 \%$ are holders of HND, Masters Respectively and none $(0 \%)$ are $\mathrm{OND} /$ Certificate and $\mathrm{PhD}$ holder. Overall, $75.3 \%$ of the respondents have already earned a bachelor degree, while $5.5 \%, 18.7 \%$,

Table 5: Demographic Information of Respondents

\begin{tabular}{lcccccccc}
\hline \multicolumn{1}{c}{ Characteristics } & IHE & $\mathbf{\%}$ & AHE & $\mathbf{\%}$ & SHE & $\mathbf{\%}$ & Total & Percentage \\
\hline Gender & & & & & & & & \\
Male & 108 & 84.4 & 48 & 81.4 & 32 & 100 & 188 & 85.8 \\
Female & 28 & 15.6 & 11 & 18.6 & 0 & 0 & 31 & 14.2 \\
Total & $\mathbf{1 2 8}$ & $\mathbf{1 0 0}$ & $\mathbf{5 9}$ & $\mathbf{1 0 0}$ & $\mathbf{3 2}$ & $\mathbf{1 0 0}$ & $\mathbf{2 1 9}$ & $\mathbf{1 0 0 . 0}$ \\
$\begin{array}{l}\text { Age Group } \\
\text { (Years) }\end{array}$ & & & & & & & & \\
Below 20 & 0 & 0 & 0 & 0 & 0 & 0 & 0 & \\
$21-29$ & 14 & 10.9 & 0 & 0 & 0 & 0 & 14 & 6.4 \\
$30-39$ & 62 & 48.4 & 45 & 76.3 & 19 & 59.4 & 126 & 57.5 \\
40 and Above & 52 & 40.6 & 14 & 23.7 & 13 & 40.6 & 79 & 36.1 \\
Total & $\mathbf{1 2 8}$ & $\mathbf{1 0 0}$ & $\mathbf{5 9}$ & $\mathbf{1 0 0}$ & $\mathbf{3 2}$ & $\mathbf{1 0 0}$ & $\mathbf{2 1 9}$ & $\mathbf{1 0 0 . 0}$ \\
Respondent's & & & & & & & & \\
Educational & & & & & & & & \\
Qualification & & & & & & & \\
OND/Certificates & 0 & 0 & 0 & 0 & 0 & 0 & 0 & 0 \\
HND & 8 & 6.3 & 3 & 5.1 & 1 & 3.1 & 12 & 5.5 \\
BTech/BSc & 91 & 71.1 & 51 & 86.4 & 23 & 71.9 & 165 & 75.3 \\
Masters & 28 & 21.9 & 5 & 8.5 & 8 & 25.0 & 41 & 18.7 \\
PhD & 1 & 0.8 & 0 & 0 & 0 & 0 & 1 & .5 \\
Total & $\mathbf{1 2 8}$ & $\mathbf{1 0 0}$ & $\mathbf{5 9}$ & $\mathbf{1 0 0}$ & $\mathbf{3 2}$ & $\mathbf{1 0 0}$ & $\mathbf{2 1 9}$ & $\mathbf{1 0 0 . 0}$ \\
\hline
\end{tabular}

\section{Researcher's Field Report (2019)}

and $0.5 \%$ are holders of HND, Masters and PhD Respectively. This might be an implication that they are well informed, and possessed the ability to assess and process information (tangible 
and intangible benefit accrue to the use of Solar PV) toward making a decision in line with the utilization of a Solar PV.

\section{Socio-economic Information of the Respondents}

This section discussed the socio-economic information of the respondents. First, the researcher sought to establish the Family structure of the households. Their responses are highlighted in Table 6. In Ijapo Housing Estate (IHE), 75.8\% of the respondents are married with dependents, $13.3 \%$ are single with no dependent, $7.8 \%$ are single with dependents, and $3.1 \%$ are married with no dependent. In Alagbaka Housing Estate (AHE), 94.9\% of the respondents are married with dependents, $3.4 \%$ are single with dependents, $1.7 \%$ are married with no dependent, and none $(0 \%)$ are single with no dependent. In Sunshine Housing Estate (SHE), 93.7\% of the respondents are married with dependents, 6.3\% are married with no dependent, and none $(0 \%)$ are single with dependents and single with no dependent. Overall, $83.6 \%$ of the respondents are married with dependents, 3.2\% are married with no dependent, $7.8 \%$ are single with no dependents, and 5.5\% are single with dependents. This shows that the largest population of the respondent have high energy demand. Table 6 further reveals the number of people per household. The result shows that in Ijapo Housing Estate (IHE), $77.3 \%$ of the respondents have 2 - 5 people living in their house. $11.7 \%$ have $6-9$ people living in their house, $0.8 \%$ have above 9 people living in their house, and $10.2 \%$ are staying alone. In Alagbaka Housing Estate (AHE), 93.2\% of the respondents have 2 - 5 people living in their house. 6.8\% have $6-9$ people living in their house, none (0\%) are staying alone and have above 9 people living in their house. In Sunshine Housing Estate (SHE), 96.9\% of the respondents have $2-5$ people living in their house. 3.1\% have $6-9$ people living in their house, none (0\%) are staying alone and have above 9 people living in their house. Overall, majority (84.5\%) of the respondents have $2-5$ people living in their house. $9.1 \%$ have $6-9$ people living in their house, $0.5 \%$ have above 9 people living in their house and $5.9 \%$ are staying alone. This align with the work of Olaniyan, McLellan, Ogata and Tezuka, 2018 [28] that in the urban areas there are fewer people per household. Table 6 also shows the income distribution of the household. The result also shows that in Ijapo Housing Estate (IHE), 48.4\% of the respondents earns \#100,000 - \#250,000 per month, 32\% earns \#250,000 - \#500,000 monthly, 11\% earns Below $\# 100,000$, 6.3\% earns \#500,000 - \#1,000,000 and 1.6\% earns above \#1,000,000 per month. In Alagbaka Housing Estate (AHE), 81.4\% of the respondents earns \#100,000 - \#250,000 per month, 13.6\% earns \#250,000 - \#500,000 monthly, 5.1\% earns \#500,000 - \#1,000,000 and none $(0 \%)$ earns Below \#100,000, and above \#1,000,000 per month. In Sunshine Housing Estate (SHE), 68.8\% of the respondents earns \#100,000 - \#250,000 per month, 31.2\% earns \#250,000 - \#500,000 monthly, 
Table 6: Socio-economic Information of the respondents

\begin{tabular}{|c|c|c|c|c|c|c|c|c|}
\hline Characteristics & IHE & $\%$ & AHE & $\%$ & SHE & $\%$ & TOTAL & $\%$ \\
\hline \multicolumn{9}{|l|}{ Family Structure } \\
\hline Single (no dependent) & 17 & 13.3 & 0 & 0 & 0 & 0 & 17 & 7.8 \\
\hline Single (with dependents) & 10 & 7.8 & 2 & 3.4 & 0 & 0 & 12 & 5.5 \\
\hline Married (no dependent) & 4 & 3.1 & 1 & 1.7 & 2 & 6.3 & 7 & 3.2 \\
\hline Married (with Dependents) & 97 & 75.8 & 56 & 94.9 & 30 & 93.7 & 183 & 83.6 \\
\hline Total & 128 & 100 & 59 & 100 & 32 & 100 & 219 & 100.0 \\
\hline \multicolumn{9}{|l|}{$\begin{array}{l}\text { Number of People per } \\
\text { household }\end{array}$} \\
\hline 1 & 13 & 10.2 & 0 & 0 & 0 & 0 & 13 & 5.9 \\
\hline $2-5$ & 99 & 77.3 & 55 & 93.2 & 31 & 96.9 & 185 & 84.5 \\
\hline $6-9$ & 15 & 11.7 & 4 & 6.8 & 1 & 3.1 & 20 & 9.1 \\
\hline above 9 & 1 & 0.8 & 0 & 0 & 0 & 0 & 1 & .5 \\
\hline Total & 128 & 100 & 59 & 100 & 32 & 100 & 219 & 100.0 \\
\hline \multicolumn{9}{|l|}{ Monthly Income } \\
\hline Below \#100,000 & 15 & 11.7 & 0 & 0 & 0 & 0 & 15 & 6.8 \\
\hline$\# 100,000-\# 250,000$ & 62 & 48.4 & 48 & 81.4 & 22 & 68.8 & 132 & 60.3 \\
\hline$\# 250,000-500,000$ & 41 & 32.0 & 8 & 13.6 & 10 & 31.2 & 59 & 26.9 \\
\hline$\# 500,000-\# 1,000,000$ & 8 & 6.3 & 3 & 5.1 & 0 & 0 & 11 & 5.0 \\
\hline above $\# 1,000,000$ & 2 & 1.6 & 0 & 0 & 0 & 0 & 2 & .9 \\
\hline Total & 128 & 100 & 59 & 100 & 32 & 100 & 219 & 100.0 \\
\hline \multicolumn{9}{|l|}{ Average Monthly electricity } \\
\hline \multicolumn{9}{|l|}{ Bill } \\
\hline Below \#5,000 & 15 & 11.7 & 0 & 0 & 10 & 31.2 & 25 & 11.4 \\
\hline \#5000- \#10,000 & 35 & 27.3 & 40 & 67.8 & 20 & 62.5 & 95 & 43.4 \\
\hline$\# 10,000-\# 15,000$ & 45 & 35.2 & 14 & 23.7 & 2 & 6.3 & 61 & 27.9 \\
\hline$\# 15,000-20,000$ & 25 & 19.5 & 3 & 5.1 & 0 & 0 & 28 & 12.8 \\
\hline above \#20,000 & 0.8 & 6.3 & 2 & 3.4 & 0 & 0 & 10 & 4.6 \\
\hline Total & 128 & 100 & 59 & 100 & 32 & 100 & 219 & 100.0 \\
\hline
\end{tabular}

Researcher's Field Report (2019)

and none (0\%) earns below \#100,000, between\#500,000 - \#1,000,000, and above \#1,000,000 per month. Overall, $60.3 \%$ of the respondents earns \#100,000 - \#250,000 per month, 26.9\% earns \#250,000 - \#500,000 monthly, 6.8\% earns Below \#100,000, 5\% earns \#500,000 $\# 1,000,000$ and $0.9 \%$ earns above \#1,000,000 per month. Table 6 further reveals that in Ijapo Housing Estate (IHE), 27.3\% pay \#5,000 - \#10,000 for electricity bill per month. 35.2\% pay $\# 10,000$ - \#15,000, 19.5\% pay \#15,000 - \#20,000, $6.3 \%$ pay above \#20,000 and 11.7\% pay below \#5,000 for electricity bill per month. In Alagbaka Housing Estate (AHE), 67.8\% pay $\# 5,000$ - \#10,000 for electricity bill per month. 23.7\% pay \#10,000 - \#15,000, 5.1\% pay $\# 15,000$ - \#20,000, and $3.4 \%$ pay above \#20,000 and none $(0 \%)$ pay below \#5,000 for electricity bill per month. In Sunshine Housing Estate (SHE), 62.5\% pay \#5,000 - \#10,000 for electricity bill per month. 6.3\% pay \#10,000 - \#15,000, 31.2\% pay below \#5,000 and none (0\%) pay \#15,000 - \#20,000 and above \#20,000 for electricity bill per month. Overall, 43.4\% pay \#5,000 - \#10,000 for electricity bill per month. 27.9\% pay \#10,000 - \#15,000, 12.8\% pay $\# 15,000$ - \#20,000, 4.6 \% pay above \#20,000 and 11.4\% pay below \#5,000 for electricity bill per month.

\section{Analysis of Research Objective}

\section{Share of Solar PV in the energy mix for energy services in the study area}

Calculation of energy intensity is essential to determine the demand for various energy services in the study areas. Variables such as technical efficiency of various end-use appliances (usually referred to as the end-use appliances power ratings in kilowatts), stock and duration 
of use of these appliances and sources of fuel for powering them were identified and obtained from the survey as shown in Table 9-12. Table 9 presents the Energy Demand in Ijapo Housing Estate (KWh/Household/Day). The table reveals the average number of energy-saving bulbs in use per household per day in the estate is 14.0, Average wattage of energy-saving bulbs is 19.2, Average hours of usage of energy-saving bulbs per Household per day is 7.8, and the Total energy-saving bulbs usage is $2.24 \mathrm{KWh} / \mathrm{HH} /$ day. The average number of Incandescent bulbs in use per household per day in the estate is 0.7, Average wattage of Incandescent bulbs is 11.1, Average hours of usage of Incandescent bulbs per Household per day is 1.3, and the Total Incandescent bulbs usage is $0.32 \mathrm{KWh} / \mathrm{HH} /$ day. The average number of Rechargeable Lamps in use per household per day in the estate is 1.6, Average wattage of Rechargeable Lamps is 5.3, Average hours of usage of Rechargeable Lamps per Household per day is 2.0, and the Total Rechargeable Lamps usage is $0.02 \mathrm{KWh} / \mathrm{HH} /$ day. There is no usage of Fluorescent Lamp, Solar Torch, Solar Lantern, Kerosene Lantern, Gas Lamp, and Candlesticks in the Estate. The average number of End-Use Appliance for Lighting Services per household per day in the estate is 16.3, Average wattage of End-Use Appliance for Lighting Services is 35.6, Average hours of usage of End-Use Appliance for Lighting 
Table 9: Energy Demand in Ijapo Housing Estate (KWh/Household/Day)

\begin{tabular}{|c|c|c|c|c|}
\hline Energy Services & $\begin{array}{l}\text { Ave. No of Appl. } \\
\text { in use } \\
\text { /Household/day }\end{array}$ & $\begin{array}{l}\text { Appliance } \\
\text { wattage }\end{array}$ & $\begin{array}{l}\text { Ave. usage } \\
\text { hours per } \\
\text { HH per Day }\end{array}$ & $\begin{array}{l}\text { Total Appl. Usage } \\
\text { (KWh/HH/day) }\end{array}$ \\
\hline Energy saving Bulbs & 14.0 & 19.2 & 7.8 & 2.24 \\
\hline Fluorescent Lambs & 0 & 0 & 0 & 0 \\
\hline Incandescent Bulbs & 0.7 & 11.1 & 1.3 & 0.32 \\
\hline Rechargeable Lambs & 1.6 & 5.3 & 2.0 & 0.02 \\
\hline Solar Touches & 0 & 0 & 0 & 0 \\
\hline Solar Lanterns & 0 & 0 & 0 & 0 \\
\hline Kerosene Lanterns & 0 & 0 & 0 & 0 \\
\hline Gas Lambs & 0 & 0 & 0 & 0 \\
\hline Candle Sticks & 0 & 0 & 0 & 0 \\
\hline $\begin{array}{l}\text { End-Use Appliances for } \\
\text { Lighting Services }\end{array}$ & 16.3 & 35.6 & 11.1 & 2.58 \\
\hline Laptop/desktop & 1.1 & 52.2 & 2.5 & 0.25 \\
\hline Power Stabilizers & 2.1 & 45.3 & 7.7 & 0.90 \\
\hline UPS, Printers & 0 & 0 & 0 & 0 \\
\hline Phone/ tablet & 3.7 & 9.3 & 4.4 & 0.16 \\
\hline Solar Calculators & 0 & 0 & 0 & 0 \\
\hline Game Consoles & 0.1 & 10.2 & 0.3 & 0.03 \\
\hline $\begin{array}{l}\text { End-Use Appliances for } \\
\text { Computing/Internet } \\
\text { Services }\end{array}$ & 7.0 & 116.5 & 14.9 & 1.35 \\
\hline Radio/TV/Videos & 3.3 & 68.4 & 5.0 & 1.22 \\
\hline Musical Instruments & 0 & 0 & 0 & 0 \\
\hline $\begin{array}{l}\text { End-Use Appliances for } \\
\text { Entertainment Services }\end{array}$ & 3.3 & 68.4 & 5.0 & 1.22 \\
\hline Shaving Kits & 0 & 0 & 0 & 0 \\
\hline Washing machine & 0.6 & 350.8 & 0.3 & 0.19 \\
\hline Blender & 0.9 & 532.8 & 0.2 & 0.13 \\
\hline Iron & 1 & 1227.6 & 0.3 & 0.41 \\
\hline $\begin{array}{l}\text { End-Use Appliances for } \\
\text { Process Heat }\end{array}$ & 2.5 & 2101.6 & 0.8 & 0.73 \\
\hline Firewood Stove & 0 & 0 & 0 & 0 \\
\hline Kerosene Stove & 0 & 0 & 0 & 0 \\
\hline Improved Firewood Stove & 0 & 0 & 0 & 0 \\
\hline Gas Cooker & 1 & $\mathrm{~kg}$ & 2.6 & - \\
\hline Electric cooker & 0.8 & 2143.7 & 1.9 & 5.48 \\
\hline $\begin{array}{l}\text { End-Use Appliances for } \\
\text { Cooking Services }\end{array}$ & 1.8 & 2143.7 & 4.5 & 5.48 \\
\hline $\begin{array}{l}\text { Water Pumping Machine } \\
\text { (Drinking) }\end{array}$ & 0.8 & 749.2 & 0.4 & 0.42 \\
\hline $\begin{array}{l}\text { Water Pumping Machine } \\
\text { (Irrigation) }\end{array}$ & 0 & 0 & 0 & 0 \\
\hline $\begin{array}{l}\text { End-Use Appliances for } \\
\text { Water Pumping Services }\end{array}$ & 0.8 & 749.2 & 0.4 & 0.42 \\
\hline $\begin{array}{l}\text { End-Use Appliances for } \\
\text { Refrigeration }\end{array}$ & 1.5 & 283.4 & 19.6 & 10.5 \\
\hline Fan & 3.7 & 67.7 & 4.2 & 1.1 \\
\hline Air condition & 0.2 & 196.9 & 0.5 & 1.93 \\
\hline $\begin{array}{l}\text { End-Use Appliances for } \\
\text { Ventilation }\end{array}$ & 3.9 & 264.5 & 4.7 & 3.03 \\
\hline TOTAL & 37.1 & 5762.9 & 64 & 25.31 \\
\hline
\end{tabular}


Services per Household per day is 11.1, and the Total End-Use Appliance for Lighting Services daily usage is $2.58 \mathrm{KWh} / \mathrm{HH} /$ day. The average number of Laptop/ Desktop in use per household per day in the estate is 1.1, Average wattage of Laptop/ Desktop is 52.2, Average hours of usage of Laptop/ Desktop per Household per day is 2.5, and the Total Laptop/ Desktop usage is $0.25 \mathrm{KWh} / \mathrm{HH} /$ day. The average number of Power Stabilizer in use per household per day in the estate is 2.1, Average wattage of Power stabilizer is 45.3, Average hours of usage of Power Stabilizer per Household per day is 7.7, and the Total Power Stabilizer usage is $0.90 \mathrm{KWh} / \mathrm{HH} /$ day. The average number of Phone/ tablet in use per household per day in the estate is 3.7, Average wattage of Phone/ tablet is 9.3, Average hours of usage of Phone/ tablet per Household per day is 4.4 , and the Total Phone/ tablet usage is $0.16 \mathrm{KWh} / \mathrm{HH} /$ day. The average number of Game Console in use per household per day in the estate is 0.1 , Average wattage of Game Console is 10.2, Average hours of usage of Game Console per Household per day is 0.3 , and the Total Game Console usage is $0.03 \mathrm{KWh} / \mathrm{HH} /$ day. There is no usage of UPS, Printers and Solar Calculator in the Estate. The average number of End-Use Appliance for Computing/Internet Services per household per day in the estate is 7.0, Average wattage of End-Use Appliance for Computing/Internet Services is 116.5, Average hours of usage of EndUse Appliance for Computing/Internet Services per Household per day is 14.9, and the Total End-Use Appliance for Computing/Internet Services daily usage is $1.35 \mathrm{KWh} / \mathrm{HH} / \mathrm{day}$. The average number of Radio/Television/Video in use per household per day in the estate is 3.3, Average wattage of Radio/Television/Video is 68.4, Average hours of usage of Radio/Television/Video per Household per day is 5.0, and the Total Radio/Television/Video usage is $1.22 \mathrm{KWh} / \mathrm{HH} / \mathrm{day}$. There is no usage of Musical Instruments in the Estate. The average number of End-Use Appliance for Entertainment Services per household per day in the estate is 3.3, Average wattage of End-Use Appliance for Entertainment Services is 68.4, Average hours of usage of End-Use Appliance for Entertainment Services per Household per day is 5.0, and the Total End-Use Appliance for Entertainment Services daily usage is $1.22 \mathrm{KWh} / \mathrm{HH} /$ day. The average number of Washing Machine in use per household per day in the estate is 0.6, Average wattage of Washing Machine is 350.8, Average hours of usage of Washing Machine per Household per day is 0.3, and the Washing Machine usage is $0.19 \mathrm{KWh} / \mathrm{HH} /$ day. The average number of Blender in use per household per day in the estate is 0.9, Average wattage of Blender is 532.8, Average hours of usage of Blender per Household per day is 0.2, and the Total Blender usage is $0.19 \mathrm{KWh} / \mathrm{HH} /$ day. The average number of Iron in use per household per day in the estate is 1, Average wattage of Iron is 1227.6, Average hours of usage of Iron per Household per day is 0.3 , and the Total Iron usage is $0.41 \mathrm{KWh} / \mathrm{HH} /$ day. There is no usage of Shaving kits in the Estate. The average number of End-Use Appliance for Process heat per household per day in the estate is 2.5, Average wattage of End-Use Appliance for Process Heat is 2101.6, Average hours of usage of End-Use Appliance for Process Heat per Household per day is 0.8, and the Total End-Use Appliance for Process Heat daily usage is $0.73 \mathrm{KWh} / \mathrm{HH} /$ day. The average number of Gas Cooker in use per household per day in the estate is 1 , and Average hours of usage of Gas Cooker per Household per day is 2.6. The average number of Electric Cooker in use per household per day in the estate is 0.8, Average wattage of Electric Cooker is 2143.7, Average hours of usage of Electric Cooker per Household per day is 1.9, and the Total Electric Cooker usage is $5.48 \mathrm{KWh} / \mathrm{HH} /$ day. There is no usage of Firewood Stove, Kerosene Stove and Improved Firewood Stove in the Estate. The average number of End-Use Appliance for Cooking Services per household per day in the estate is 1.8, Average wattage of End-Use Appliance for Cooking Services is 2143.7, Average hours of usage of End-Use Appliance for Cooking Services per Household per day is 4.5, and the Total End-Use Appliance for Cooking Services daily usage is $5.48 \mathrm{KWh} / \mathrm{HH} /$ day. . The average number of Water Pumping Machine for Drinking in use per household per day in the estate is 0.8, Average wattage of Water Pumping Machine for Drinking is 749.2, Average hours of usage of Water Pumping Machine for Drinking per Household per day is 0.4 , and the Total Water Pumping Machine for drinking usage is 
$0.42 \mathrm{KWh} / \mathrm{HH} /$ day. There is no usage of Water Pumping Machine for irrigation in the Estate. The average number of End-Use Appliance for Water Pumping Services per household per day in the estate is 0.8, Average wattage of End-Use Appliance for Water Pumping Services is 749.2, Average hours of usage of End-Use Appliance for Water Pumping Services per Household per day is 0.4, and the Total End-Use Appliance for Water Pumping Services daily usage is $0.42 \mathrm{KWh} / \mathrm{HH} /$ day. The average number of End-Use Appliance for Refrigeration per household per day in the estate is 1.5, Average wattage of End-Use Appliance for Refrigeration is 283.4, Average hours of usage of End-Use Appliance for Refrigeration per Household per day is 19.6, and the Total End-Use Appliance for Refrigeration daily usage is $10.5 \mathrm{KWh} / \mathrm{HH} /$ day. The average number of Fan in use per household per day in the estate is 3.7, Average wattage of Fan is 67.7, Average hours of usage of Fan per Household per day is 4.2, and the Total Fan usage is $1.1 \mathrm{KWh} / \mathrm{HH} /$ day. The average number of Air Condition in use per household per day in the estate is 0.2, Average wattage of Air Condition is 196.9, Average hours of usage of Air Condition per Household per day is 0.5, and the Total Fan Air Condition usage is 1.93KWh/HH/day. The average number of End-Use Appliance for Ventilation Services per household per day in the estate is 3.9, Average wattage of End-Use Appliance for Ventilation Services is 264.5, Average hours of usage of End-Use Appliance for Ventilation Services per Household per day is 4.7, and the Total End-Use Appliance for Ventilation Services daily usage is $3.03 \mathrm{KWh} / \mathrm{HH} /$ day. The Total daily per household for all energy services is $25.31 \mathrm{Kwh} / \mathrm{HH} /$ day, as shown in Table 9.

Table 10 presents the Energy Demand in Alagbaka Housing Estate (KWh/Household/Day). The table reveals the average number of energy-saving bulbs in use per household per day in the estate is 16.2, Average wattage of energy-saving bulbs is 17.7, Average hours of usage of energy-saving bulbs per Household per day is 7.7, and the Total energy-saving bulbs usage is $2.29 \mathrm{KWh} / \mathrm{HH} /$ day. The average number of Rechargeable Lamps in use per household per day in the estate is 2.1, Average wattage of Rechargeable Lamps is 4.2, Average hours of usage of Rechargeable Lamps per Household per day is 2.5, and the Total Rechargeable Lamps usage 
Table 10: Energy Demand in Alagbaka Housing Estate (KWh/Household/Day)

\begin{tabular}{|c|c|c|c|c|}
\hline Energy Services & $\begin{array}{l}\text { Ave. No of Appl. } \\
\text { in use } \\
\text { /Household/day }\end{array}$ & $\begin{array}{l}\text { Appliance } \\
\text { wattage }\end{array}$ & $\begin{array}{l}\text { Ave. usage } \\
\text { hours per HH } \\
\text { per Day }\end{array}$ & $\begin{array}{c}\text { Total Appl. } \\
\text { Usage } \\
\text { (KWh/HH/day) }\end{array}$ \\
\hline Energy saving Bulbs & 16.2 & 17.7 & 7.7 & 2.29 \\
\hline Fluorescent Lambs & 0 & 0 & 0 & 0 \\
\hline Incandescent Bulbs & 0 & 0 & 0 & 0 \\
\hline Rechargeable Lambs & 2.1 & 4.2 & 2.5 & 0.03 \\
\hline Solar Touches & 0 & 0 & 0 & 0 \\
\hline Solar Lanterns & 0 & 0 & 0 & 0 \\
\hline Kerosene Lanterns & 0 & 0 & 0 & 0 \\
\hline Gas Lambs & 0 & 0 & 0 & 0 \\
\hline Candle Sticks & 0 & 0 & 0 & 0 \\
\hline $\begin{array}{l}\text { End-Use Appliances for } \\
\text { Lighting Services }\end{array}$ & 18.3 & 21.9 & 10.2 & 2.32 \\
\hline Laptop/desktop & 1.7 & 74.8 & 3.4 & 0.44 \\
\hline Power Stabilizers & 2.1 & 50 & 6.4 & 0.66 \\
\hline UPS, Printers & 0 & 0 & 0 & 0 \\
\hline Phone/ tablet & 4.0 & 5.8 & 3.4 & 0.08 \\
\hline Solar Calculators & 0 & 0 & 0 & 0 \\
\hline Game Consoles & 0.03 & 3.2 & 0.07 & 0.01 \\
\hline $\begin{array}{l}\text { End-Use Appliances for } \\
\text { Computing/Internet } \\
\text { Services }\end{array}$ & 7.9 & 133.8 & 13.2 & 1.18 \\
\hline Radio/TV/Videos & 4.0 & 72.9 & 5.6 & 1.69 \\
\hline Musical Instruments & 0 & 0 & 0 & 0 \\
\hline $\begin{array}{l}\text { End-Use Appliances for } \\
\text { Entertainment Services }\end{array}$ & 4.0 & 72.9 & 5.6 & 1.69 \\
\hline Shaving Kits & 0 & 0 & 0 & 0 \\
\hline Washing machine & 0.9 & 516.9 & 0.4 & 0.21 \\
\hline Blender & 1 & 532.2 & 0.25 & 0.14 \\
\hline Iron & 1 & 1100 & 0.27 & 0.3 \\
\hline $\begin{array}{l}\text { End-Use Appliances for } \\
\text { Process Heat }\end{array}$ & 2.9 & 2149.2 & 0.9 & 0.64 \\
\hline Firewood Stove & 0 & 0 & 0 & 0 \\
\hline Kerosene Stove & 0 & 0 & 0 & 0 \\
\hline Improved Firewood Stove & 0 & 0 & 0 & 0 \\
\hline Gas Cooker & 1 & $\mathrm{~kg}$ & 2.8 & - \\
\hline Electric cooker & 0.7 & 2194.9 & 1.9 & 6.1 \\
\hline $\begin{array}{l}\text { End-Use Appliances for } \\
\text { Cooking Services }\end{array}$ & 1.7 & 2194.9 & 4.7 & 6.1 \\
\hline $\begin{array}{l}\text { Water Pumping Machine } \\
\text { (Drinking) }\end{array}$ & 0.4 & 316.9 & 0.1 & 0.1 \\
\hline $\begin{array}{l}\text { Water Pumping Machine } \\
\text { (Irrigation) }\end{array}$ & 0 & 0 & 0 & 0 \\
\hline $\begin{array}{l}\text { End-Use Appliances for } \\
\text { Water Pumping Services }\end{array}$ & 0.4 & 316.9 & 0.1 & 0.1 \\
\hline $\begin{array}{l}\text { End-Use Appliances for } \\
\text { Refrigeration }\end{array}$ & 1.5 & 294.1 & 24 & 11.0 \\
\hline Fan & 4.8 & 70.0 & 4.1 & 1.45 \\
\hline Air condition & 0.4 & 237.3 & 0.6 & 4.88 \\
\hline $\begin{array}{l}\text { End-Use Appliances } \\
\text { forVentilation }\end{array}$ & 5.2 & 307.3 & 4.7 & 6.33 \\
\hline TOTAL & 41.9 & 5491 & 63.4 & 29.36 \\
\hline
\end{tabular}

Researcher's Field Report (2019) 
is $0.03 \mathrm{KWh} / \mathrm{HH} /$ day. There is no usage of Fluorescent Lamp, Incandescent bulbs, Solar Torch, Solar Lantern, Kerosene Lantern, Gas Lamp, and Candlesticks in the Estate. The average number of End-Use Appliance for Lighting Services per household per day in the estate is 18.3, Average wattage of End-Use Appliance for Lighting Services is 21.9, Average hours of usage of End-Use Appliance for Lighting Services per Household per day is 10.2, and the Total End-Use Appliance for Lighting Services daily usage is $2.32 \mathrm{KWh} / \mathrm{HH} /$ day. The average number of Laptop/ Desktop in use per household per day in the estate is 1.7, Average wattage of Laptop/ Desktop is 74.8, Average hours of usage of Laptop/ Desktop per Household per day is 3.4 , and the Total Laptop/ Desktop usage is $0.44 \mathrm{KWh} / \mathrm{HH} /$ day. The average number of Power Stabilizer in use per household per day in the estate is 2.1, Average wattage of Power Stabilizer is 50, Average hours of usage of Power Stabilizer per Household per day is 6.4, and the Total Power Stabilizer usage is $0.66 \mathrm{KWh} / \mathrm{HH} /$ day. The average number of Phone/ tablet in use per household per day in the estate is 4.0, Average wattage of Phone/ tablet is 5.8, Average hours of usage of Phone/ tablet per Household per day is 3.4, and the Total Phone/ tablet usage is $0.08 \mathrm{KWh} / \mathrm{HH} /$ day. The average number of Game Console in use per household per day in the estate is 0.03 , Average wattage of Game Console is 3.2, Average hours of usage of Game Console per Household per day is 0.07 , and the Total Game Console usage is $0.01 \mathrm{KWh} / \mathrm{HH} /$ day. There is no usage of UPS, Printers and Solar Calculator in the Estate. The average number of End-Use Appliance for Computing/Internet Services per household per day in the estate is 7.9, Average wattage of End-Use Appliance for Computing/Internet Services is 133.8, Average hours of usage of End-Use Appliance for Computing/Internet Services per Household per day is 13.2, and the Total End-Use Appliance for Computing/Internet Services daily usage is $1.18 \mathrm{KWh} / \mathrm{HH} /$ day. The average number of Radio/Television/Video in use per household per day in the estate is 4.0, Average wattage of Radio/Television/Video is 72.9, Average hours of usage of Radio/Television/Video per Household per day is 5.6, and the Total Radio/Television/Video usage is $1.69 \mathrm{KWh} / \mathrm{HH} /$ day. There is no usage of Musical Instruments in the Estate. The average number of End-Use Appliance for Entertainment Services per household per day in the estate is 4.0, Average wattage of End-Use Appliance for Entertainment Services is 72.9, Average hours of usage of End-Use Appliance for Entertainment Services per Household per day is 5.6, and the Total End-Use Appliance for Entertainment Services daily usage is $1.69 \mathrm{KWh} / \mathrm{HH} /$ day. The average number of Washing Machine in use per household per day in the estate is 0.9, Average wattage of Washing Machine is 516.9, Average hours of usage of Washing Machine per Household per day is 0.4, and the Washing Machine usage is $0.21 \mathrm{KWh} / \mathrm{HH} /$ day. The average number of Blender in use per household per day in the estate is 1, Average wattage of Blender is 532.2, Average hours of usage of Blender per Household per day is 0.25 , and the Total Blender usage is $0.14 \mathrm{KWh} / \mathrm{HH} /$ day. The average number of Iron in use per household per day in the estate is 1 , Average wattage of Iron is 1100 , Average hours of usage of Iron per Household per day is 0.27, and the Total Iron usage is $0.3 \mathrm{KWh} / \mathrm{HH} /$ day. There is no usage of Shaving kits in the Estate. The average number of End-Use Appliance for Process heat per household per day in the estate is 2.9, Average wattage of End-Use Appliance for Process Heat is 2149.9, Average hours of usage of End-Use Appliance for Process Heat per Household per day is 0.9, and the Total EndUse Appliance for Process Heat daily usage is $0.64 \mathrm{KWh} / \mathrm{HH} / \mathrm{day}$. The average number of Gas Cooker in use per household per day in the estate is 1, and Average hours of usage of Gas Cooker per Household per day is 2.8. The average number of Electric Cooker in use per household per day in the estate is 0.7, Average wattage of Electric Cooker is 2194.9, Average hours of usage of Electric Cooker per Household per day is 1.9, and the Total Electric Cooker usage is $6.1 \mathrm{KWh} / \mathrm{HH} /$ day. There is no usage of Firewood Stove, Kerosene Stove and Improved Firewood Stove in the Estate. The average number of End-Use Appliance for Cooking Services per household per day in the estate is 1.7, Average wattage of End-Use Appliance for Cooking 
Services is 2194.9, Average hours of usage of End-Use Appliance for Cooking Services per Household per day is 4.7, and the Total End-Use Appliance for Cooking Services daily usage is $6.1 \mathrm{KWh} / \mathrm{HH} /$ day. . The average number of Water Pumping Machine for Drinking in use per household per day in the estate is 0.4, Average wattage of Water Pumping Machine for Drinking is 316.9, Average hours of usage of Water Pumping Machine for Drinking per Household per day is 0.1, and the Total Water Pumping Machine for drinking usage is $0.1 \mathrm{KWh} / \mathrm{HH} /$ day. There is no usage of Water Pumping Machine for irrigation in the Estate. The average number of End-Use Appliance for Water Pumping Services per household per day in the estate is 0.4, Average wattage of End-Use Appliance for Water Pumping Services is 316.9, Average hours of usage of End-Use Appliance for Water Pumping Services per Household per day is 0.1 , and the Total End-Use Appliance for Water Pumping Services daily usage is $0.1 \mathrm{KWh} / \mathrm{HH} /$ day. The average number of End-Use Appliance for Refrigeration per household per day in the estate is 1.5, Average wattage of End-Use Appliance for Refrigeration is 294.1, Average hours of usage of End-Use Appliance for Refrigeration per Household per day is 24, and the Total End-Use Appliance for Refrigeration daily usage is $11 \mathrm{KWh} / \mathrm{HH} /$ day. The average number of Fan in use per household per day in the estate is 4.8, Average wattage of Fan is 70.0, Average hours of usage of Fan per Household per day is 4.1, and the Total Fan usage is $1.45 \mathrm{KWh} / \mathrm{HH} /$ day. The average number of Air Condition in use per household per day in the estate is 0.4, Average wattage of Air Condition is 237.3, Average hours of usage of Air Condition per Household per day is 0.6, and the Total Air Condition usage is $4.88 \mathrm{KWh} / \mathrm{HH} /$ day. The average number of End-Use Appliance for Ventilation Services per household per day in the estate is 5.2, Average wattage of End-Use Appliance for Ventilation Services is 307.3, Average hours of usage of End-Use Appliance for Ventilation Services per Household per day is 4.7, and the Total End-Use Appliance for Ventilation Services daily usage is $6.33 \mathrm{KWh} / \mathrm{HH} / \mathrm{day}$. The Total daily per household for all energy services is $29.36 \mathrm{Kwh} / \mathrm{HH} /$ day as shown in Table 10 .

Table 11 presents the Energy Demand for Sunshine Housing Estate (KWh/Household/Day). The table reveals the average number of energy-saving bulbs in use per household per day in the estate is 17.6, Average wattage of energy-saving bulbs is 17.6, Average hours of usage of energy-saving bulbs per Household per day is 6, and the Total energy-saving bulbs usage is $1.87 \mathrm{KWh} / \mathrm{HH} /$ day. The average number of Rechargeable Lamps in use per household per day in the estate is 2.0, Average wattage of Rechargeable Lamps is 5.0, Average hours of usage of Rechargeable Lamps per Household per day is 2.1, and the Total Rechargeable Lamps usage is $0.02 \mathrm{KWh} / \mathrm{HH} /$ day. There is no usage of Fluorescent Lamp, Incandescent bulbs, Solar Torch, Solar Lantern, Kerosene Lantern, Gas Lamp, and Candlesticks in the Estate. The average number of End-Use Appliance for Lighting Services per household per day in the estate is 19.6, Average wattage of End-Use Appliance for Lighting Services is 22.6, Average hours of usage of End-Use Appliance for Lighting Services per Household per day is 8.1, and the Total End-Use Appliance for Lighting Services daily usage is $1.89 \mathrm{KWh} / \mathrm{HH} /$ day. The average number of Laptop/ Desktop in use per household per day in the estate is 1.9, Average wattage of Laptop/ Desktop is 63.5, Average hours of usage of Laptop/ Desktop per Household per day is 2.9, and the Total Laptop/ Desktop usage is $0.37 \mathrm{KWh} / \mathrm{HH} /$ day. The average number of Power Stabilizer in use per household per day in the estate is 2.7, Average wattage of Power Stabilizer is 50, Average hours of usage of Power Stabilizer per Household per day is 6, and the Total Power Stabilizer usage is $0.82 \mathrm{KWh} / \mathrm{HH} /$ day. The average number of Phone/ tablet in use per household per day in the estate is 3.9, Average wattage of Phone/ tablet is 8.1, Average hours of usage of Phone/ tablet per Household per day is 3.9, and the Total Phone/ tablet usage is $0.12 \mathrm{KWh} / \mathrm{HH} /$ day. The average number of Game Console in use per household per day in the estate is 1 , Average wattage of Game Console is 74.9, Average hours of usage of Game Console 
Table 11: Energy Demand in Sunshine Housing Estate (KWh/Household/Day)

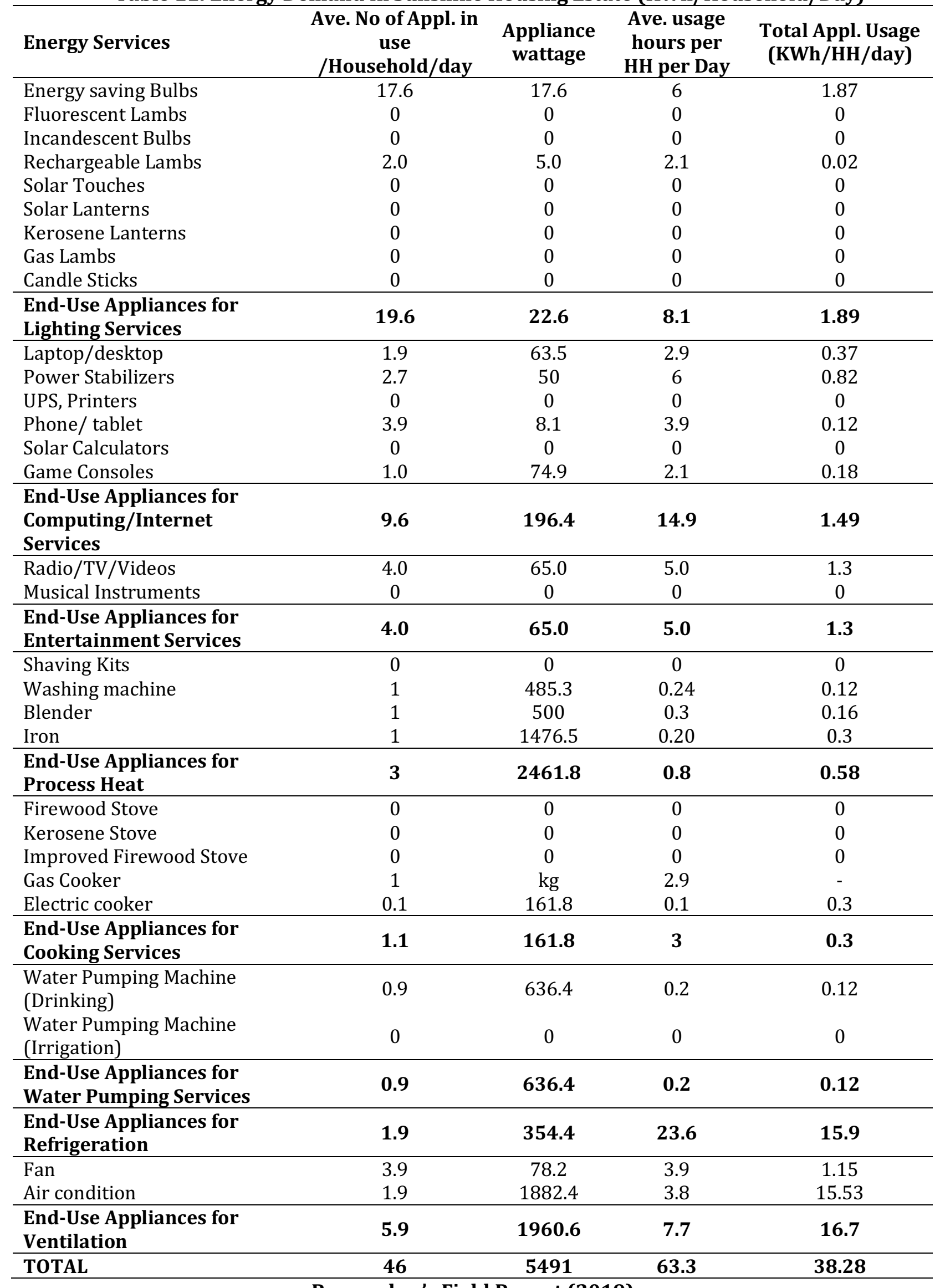

Researcher's Field Report (2019) 
per Household per day is 2.1, and the Total Game Console usage is $0.18 \mathrm{KWh} / \mathrm{HH} /$ day. There is no usage of UPS, Printers and Solar Calculator in the Estate. The average number of End-Use Appliance for Computing/Internet Services per household per day in the estate is 9.6, Average wattage of End-Use Appliance for Computing/Internet Services is 196.4, Average hours of usage of End-Use Appliance for Computing/Internet Services per Household per day is 14.9, and the Total End-Use Appliance for Computing/Internet Services daily usage is $1.49 \mathrm{KWh} / \mathrm{HH} /$ day. The average number of Radio/Television/Video in use per household per day in the estate is 4.0, Average wattage of Radio/Television/Video is 65.0, Average hours of usage of Radio/Television/Video per Household per day is 5.0, and the Total Radio/Television/Video usage is $1.3 \mathrm{KWh} / \mathrm{HH} /$ day. There is no usage of Musical Instruments in the Estate. The average number of End-Use Appliance for Entertainment Services per household per day in the estate is 4.0, Average wattage of End-Use Appliance for Entertainment Services is 65.0, Average hours of usage of End-Use Appliance for Entertainment Services per Household per day is 5.0, and the Total End-Use Appliance for Entertainment Services daily usage is $1.3 \mathrm{KWh} / \mathrm{HH} /$ day. The average number of Washing Machine in use per household per day in the estate is 1, Average wattage of Washing Machine is 485.3, Average hours of usage of Washing Machine per Household per day is 0.24, and the Washing Machine usage is $0.12 \mathrm{KWh} / \mathrm{HH} /$ day. The average number of Blender in use per household per day in the estate is 1, Average wattage of Blender is 500, Average hours of usage of Blender per Household per day is 0.3 , and the Total Blender usage is $0.16 \mathrm{KWh} / \mathrm{HH} / \mathrm{day}$. The average number of Iron in use per household per day in the estate is 1, Average wattage of Iron is 1476.5, Average hours of usage of Iron per Household per day is 0.20 , and the Total Iron usage is $0.3 \mathrm{KWh} / \mathrm{HH} /$ day. There is no usage of Shaving kits in the Estate. The average number of End-Use Appliance for Process heat per household per day in the estate is 3, Average wattage of End-Use Appliance for Process Heat is 2461.8, Average hours of usage of End-Use Appliance for Process Heat per Household per day is 0.8, and the Total End-Use Appliance for Process Heat daily usage is $0.58 \mathrm{KWh} / \mathrm{HH} /$ day. The average number of Gas Cooker in use per household per day in the estate is 1 , and Average hours of usage of Gas Cooker per Household per day is 2.9. The average number of Electric Cooker in use per household per day in the estate is 0.1, Average wattage of Electric Cooker is 161.8, Average hours of usage of Electric Cooker per Household per day is 0.1 , and the Total Electric Cooker usage is $0.3 \mathrm{KWh} / \mathrm{HH} /$ day. There is no usage of Firewood Stove, Kerosene Stove and Improved Firewood Stove in the Estate. The average number of End-Use Appliance for Cooking Services per household per day in the estate is 1.1, Average wattage of End-Use Appliance for Cooking Services is 161.8, Average hours of usage of End-Use Appliance for Cooking Services per Household per day is 3, and the Total End-Use Appliance for Cooking Services daily usage is $0.3 \mathrm{KWh} / \mathrm{HH} / \mathrm{day}$. . The average number of Water Pumping Machine for Drinking in use per household per day in the estate is 0.9, Average wattage of Water Pumping Machine for Drinking is 636.4, Average hours of usage of Water Pumping Machine for Drinking per Household per day is 0.2 , and the Total Water Pumping Machine for drinking usage is $0.12 \mathrm{KWh} / \mathrm{HH} /$ day. There is no usage of Water Pumping Machine for irrigation in the Estate. The average number of End-Use Appliance for Water Pumping Services per household per day in the estate is 0.9, Average wattage of EndUse Appliance for Water Pumping Services is 656.4, Average hours of usage of End-Use Appliance for Water Pumping Services per Household per day is 0.2 , and the Total End-Use Appliance for Water Pumping Services daily usage is $0.12 \mathrm{KWh} / \mathrm{HH} /$ day. The average number of End-Use Appliance for Refrigeration per household per day in the estate is 1.9, Average wattage of End-Use Appliance for Refrigeration is 354.4, Average hours of usage of End-Use Appliance for Refrigeration per Household per day is 23.6, and the Total End-Use Appliance for Refrigeration daily usage is $15.9 \mathrm{KWh} / \mathrm{HH} /$ day. The average number of Fan in use per household per day in the estate is 3.9, Average wattage of Fan is 78.2, Average hours of usage of Fan per Household per day is 3.9, and the Total Fan usage is $1.15 \mathrm{KWh} / \mathrm{HH} /$ day. The average 
number of Air Condition in use per household per day in the estate is 1.9, Average wattage of Air Condition is 1882.4, Average hours of usage of Air Condition per Household per day is 3.8, and the Total Air Condition usage is $15.53 \mathrm{KWh} / \mathrm{HH} /$ day. The average number of End-Use Appliance for Ventilation Services per household per day in the estate is 5.9, Average wattage of End-Use Appliance for Ventilation Services is 1960.6, Average hours of usage of End-Use Appliance for Ventilation Services per Household per day is 7.7, and the Total End-Use Appliance for Ventilation Services daily usage is $16.7 \mathrm{KWh} / \mathrm{HH} /$ day. The Total daily per household for all energy services is $38.28 \mathrm{Kwh} / \mathrm{HH} /$ day as shown in Table 11.

The Table 12 reveals the total daily per household energy use of $2.21 \mathrm{Kwh} / \mathrm{HH} /$ day for Energy saving Bulbs, $0.19 \mathrm{Kwh} / \mathrm{HH} /$ day for Incandescent Bulbs and $0.03 \mathrm{Kwh} / \mathrm{HH} /$ day for Rechargeable Lambs. Fluorescent Lamps, Solar torches, solar lanterns, Kerosene Lanterns, Gas lamps, Candlesticks which are also appliances for lighting are not in use in the study areas. The overall daily per household energy for lighting is $2.42 \mathrm{Kwh} / \mathrm{HH} /$ day. Table 4.6 also shows the total daily per household energy demand for laptops and desktop computer as $0.32 \mathrm{Kwh}$, Power stabilizer is $0.83 \mathrm{Kwh}$, phone and tablet is $0.13 \mathrm{Kwh}$, and the Game console is $0.05 \mathrm{Kwh}$. The overall daily per household energy demand for Computing and Internet Services is $1.33 \mathrm{Kwh}$. The total daily per household energy demand for entertainment stood at $1.36 \mathrm{Kwh} / \mathrm{HH} /$ day, which includes radio, TV, video and musical instruments. The total daily per household energy demand for appliances for Process heat stood at $0.69 \mathrm{Kwh} / \mathrm{HH} /$ day which includes shaving kits, washing machine $(0.19 \mathrm{Kwh} / \mathrm{HH} /$ day $)$, blender $(0.14 \mathrm{Kwh} / \mathrm{HH} /$ day $)$ and Iron (0.36Kwh/HH/day). Table 12 further reveals the total daily per household energy demand for appliances for cooking services is $4.85 \mathrm{Kwh} / \mathrm{HH} / \mathrm{day}$, which is used by the electric cooker. Other means of cooking includes firewood stove, kerosene stove and improved firewood stove but are not in use in the estates. However, the Gas cooker is commonly used for cooking in the estate with an average number of 
Table 12: Energy Demand in the study area (KWh/Household/Day)

\begin{tabular}{|c|c|c|c|c|}
\hline Energy Services & $\begin{array}{l}\text { Ave. No of Appl. } \\
\text { in use } \\
\text { /Household/day }\end{array}$ & $\begin{array}{l}\text { Appliance } \\
\text { wattage }\end{array}$ & $\begin{array}{c}\text { Ave. usage } \\
\text { hours per } \\
\text { HH per Day }\end{array}$ & $\begin{array}{c}\text { Total Appl. Usage } \\
\text { (KWh/HH/day) }\end{array}$ \\
\hline Energy saving Bulbs & 15.2 & 18.6 & 7.5 & 2.21 \\
\hline Fluorescent Lambs & 0 & 0 & 0 & 0 \\
\hline Incandescent Bulbs & 0.4 & 6.5 & 0.8 & 0.19 \\
\hline Rechargeable Lambs & 1.8 & 4.9 & 2.1 & 0.03 \\
\hline Solar Touches & 0 & 0 & 0 & 0 \\
\hline Solar Lanterns & 0 & 0 & 0 & 0 \\
\hline Kerosene Lanterns & 0 & 0 & 0 & 0 \\
\hline Gas Lambs & 0 & 0 & 0 & 0 \\
\hline Candle Sticks & 0 & 0 & 0 & 0 \\
\hline $\begin{array}{l}\text { End-Use Appliances for } \\
\text { Lighting Services }\end{array}$ & 17.4 & 30 & 17.1 & 2.42 \\
\hline Laptop/desktop & 1.4 & 60 & 2.8 & 0.32 \\
\hline Power Stabilizers & 2.2 & 47 & 7.1 & 0.83 \\
\hline UPS, Printers & 0 & 0 & 0 & 0 \\
\hline Phone/ tablet & 3.8 & 8.1 & 4.1 & 0.13 \\
\hline Solar Calculators & 0 & 0 & 0 & 0 \\
\hline Game Consoles & 0.2 & 18.4 & 0.49 & 0.05 \\
\hline $\begin{array}{l}\text { End-Use Appliances for } \\
\text { Computing/Internet } \\
\text { Services }\end{array}$ & 7.6 & 133.2 & 14.5 & 1.33 \\
\hline Radio/TV/Videos & 3.6 & 69 & 5.2 & 1.36 \\
\hline Musical Instruments & 0 & 0 & 0 & 0 \\
\hline $\begin{array}{l}\text { End-Use Appliances for } \\
\text { Entertainment Services }\end{array}$ & 3.6 & 69 & 5.2 & 1.36 \\
\hline Shaving Kits & 0 & 0 & 0 & 0 \\
\hline Washing machine & 0.8 & 417 & 0.3 & 0.19 \\
\hline Blender & 0.9 & 528 & 0.2 & 0.14 \\
\hline Iron & 1 & 1232 & 0.3 & 0.36 \\
\hline $\begin{array}{l}\text { End-Use Appliances for } \\
\text { Process Heat }\end{array}$ & 2.7 & 2177 & 0.8 & 0.69 \\
\hline Firewood Stove & 0 & 0 & 0 & 0 \\
\hline Kerosene Stove & 0 & 0 & 0 & 0 \\
\hline Improved Firewood Stove & 0 & 0 & 0 & 0 \\
\hline Gas Cooker & 1 & $\mathrm{~kg}$ & 2.7 & - \\
\hline Electric cooker & 0.7 & 1844 & 1.6 & 4.85 \\
\hline $\begin{array}{l}\text { End-Use Appliances for } \\
\text { Cooking Services }\end{array}$ & 1.7 & 1844 & 4.4 & 4.85 \\
\hline $\begin{array}{l}\text { Water Pumping Machine } \\
\text { (Drinking) }\end{array}$ & 0.7 & 621 & 0.28 & 0.29 \\
\hline $\begin{array}{l}\text { Water Pumping Machine } \\
\text { (Irrigation) }\end{array}$ & 0 & 0 & 0 & 0 \\
\hline $\begin{array}{l}\text { End-Use Appliances for } \\
\text { Water Pumping Services }\end{array}$ & 0.7 & 621 & 0.3 & 0.29 \\
\hline $\begin{array}{l}\text { End-Use Appliances for } \\
\text { Refrigeration }\end{array}$ & 1.5 & 297 & 21 & 11.5 \\
\hline Fan & 4 & 70 & 4 & 1.2 \\
\hline Air condition & 0.6 & 471 & 1 & 4.85 \\
\hline $\begin{array}{l}\text { End-Use Appliances for } \\
\text { Ventilation }\end{array}$ & 4.6 & 541 & 5 & 6.05 \\
\hline TOTAL & 39.8 & 5712.2 & 68.3 & 28.49 \\
\hline
\end{tabular}


the appliance of 1 . The total daily per household energy demand for water pumping for drinking is $0.29 \mathrm{Kwh} / \mathrm{HH} /$ day. The total daily household energy demand for refrigeration services have the highest daily per household energy use of $11.5 \mathrm{Kwh} / \mathrm{HH} /$ day. The total daily per household energy demand for appliances for Ventilation services is $6.05 \mathrm{Kwh} / \mathrm{HH} /$ day. The Total daily per household for all energy services is $28.49 \mathrm{Kwh} / \mathrm{HH} /$ day, as shown in Table 12.

Table 13 presents the Solar Energy supply for Energy services for Ijapo Housing Estate (KWh/Household/Day). The table reveals the average number of energy-saving bulbs in use per household per day in the estate is 5.6, Average wattage of energy-saving bulbs is 19.2, Average hours of usage of energy-saving bulbs per Household per day is 6.4, and the Total energy-saving bulbs usage is $0.69 \mathrm{KWh} / \mathrm{HH} /$ day. The average number of Incandescent bulbs in use per household per day in the estate is 0.01 , Average wattage of Incandescent bulbs is 0.5 , Average hours of usage of Incandescent bulbs per Household per day is 0.02 , and the Total Incandescent bulbs usage is $0.001 \mathrm{KWh} / \mathrm{HH} /$ day. The average number of Rechargeable Lamps in use per household per day in the estate is 1.6, Average wattage of Rechargeable Lamps is 5.3, Average hours of usage of Rechargeable Lamps per Household per day is 2.0, and the Total Rechargeable Lamps usage is $0.03 \mathrm{KWh} / \mathrm{HH} /$ day. There is no usage of Fluorescent Lamp, Solar Torch, Solar Lantern, Kerosene Lantern, Gas Lamp, and Candlesticks in the Estate. The average number of End-Use Appliance for Lighting Services per household per day in the estate is 7.2, Average wattage of End-Use Appliance for Lighting Services is 24.9, Average hours of usage of End-Use Appliance for Lighting Services per Household per day is 8.5, and the Total End-Use Appliance for Lighting Services daily usage is $0.72 \mathrm{KWh} / \mathrm{HH} /$ day. The average number of Laptop/ Desktop in use per household per day in the estate is 1.1, Average wattage of Laptop/ Desktop is 52.2, Average hours of usage of Laptop/ Desktop per Household per day is 2.5, and the Total Laptop/ Desktop usage is $0.23 \mathrm{KWh} / \mathrm{HH} /$ day. The average number of Power Stabilizer in use per household per day in the estate is 0.9 , 
Table 13: Solar PV supply for energy services in Ijapo Housing Estate

\begin{tabular}{|c|c|c|c|c|}
\hline Energy Services & $\begin{array}{c}\text { Ave. No of Appl. } \\
\text { in use } \\
\text { /Household/day }\end{array}$ & $\begin{array}{l}\text { Appliance } \\
\text { wattage }\end{array}$ & $\begin{array}{l}\text { Ave. usage } \\
\text { hours per } \\
\text { HH per Day }\end{array}$ & $\begin{array}{c}\text { Total Appl. Usage } \\
\text { (KWh/HH/day) }\end{array}$ \\
\hline Energy saving Bulbs & 5.6 & 19.2 & 6.4 & 0.69 \\
\hline Fluorescent Lamps & 0 & 0 & 0 & 0 \\
\hline Incandescent Bulbs & 0.01 & 0.5 & 0.02 & 0.001 \\
\hline Rechargeable Lamps & 1.6 & 5.3 & 2.0 & 0.03 \\
\hline Solar Touches & 0 & 0 & 0 & 0 \\
\hline Solar Lanterns & 0 & 0 & 0 & 0 \\
\hline Kerosene Lanterns & 0 & 0 & 0 & 0 \\
\hline Gas Lambs & 0 & 0 & 0 & 0 \\
\hline Candle Sticks & 0 & 0 & 0 & 0 \\
\hline $\begin{array}{l}\text { End-Use Appliances for } \\
\text { Lighting Services }\end{array}$ & 7.2 & 24.9 & 8.5 & 0.72 \\
\hline Laptop/desktop & 1.1 & 52.2 & 2.5 & 0.23 \\
\hline Power Stabilizers & 0.9 & 45.3 & 7.4 & 0.39 \\
\hline UPS, Printers & 0 & 0 & 0 & 0 \\
\hline Phone/ tablet & 3.7 & 9.3 & 4.3 & 0.15 \\
\hline Solar Calculators & 0 & 0 & 0 & 0 \\
\hline Game Consoles & 0.2 & 18.4 & 0.49 & 0.05 \\
\hline $\begin{array}{l}\text { End-Use Appliances for } \\
\text { Computing/Internet } \\
\text { Services }\end{array}$ & 5.7 & 106.4 & 14.2 & 0.77 \\
\hline Radio/TV/Videos & 1.0 & 68.4 & 2.9 & 0.22 \\
\hline Musical Instruments & 0 & 0 & 0 & 0 \\
\hline $\begin{array}{l}\text { End-Use Appliances for } \\
\text { Entertainment Services }\end{array}$ & 1.0 & 68.4 & 2.9 & 0.22 \\
\hline Shaving Kits & 0 & 0 & 0 & 0 \\
\hline Washing machine & 0 & 0 & 0 & 0 \\
\hline Blender & 0 & 0 & 0 & 0 \\
\hline Iron & 0 & 0 & 0 & 0 \\
\hline $\begin{array}{l}\text { End-Use Appliances for } \\
\text { Process Heat }\end{array}$ & $\mathbf{0}$ & $\mathbf{0}$ & $\mathbf{0}$ & $\mathbf{0}$ \\
\hline Firewood Stove & 0 & 0 & 0 & 0 \\
\hline Kerosene Stove & 0 & 0 & 0 & 0 \\
\hline Improved Firewood Stove & 0 & 0 & 0 & 0 \\
\hline Gas Cooker & 0 & 0 & 0 & - \\
\hline Electric cooker & 0 & 0 & 0 & 0 \\
\hline $\begin{array}{l}\text { End-Use Appliances for } \\
\text { Cooking Services }\end{array}$ & $\mathbf{0}$ & $\mathbf{0}$ & $\mathbf{0}$ & $\mathbf{0}$ \\
\hline $\begin{array}{l}\text { Water Pumping Machine } \\
\text { (Drinking) }\end{array}$ & 0 & 0 & 0 & 0 \\
\hline $\begin{array}{l}\text { Water Pumping Machine } \\
\text { (Irrigation) }\end{array}$ & 0 & 0 & 0 & 0 \\
\hline $\begin{array}{l}\text { End-Use Appliances for } \\
\text { Water Pumping Services }\end{array}$ & $\mathbf{0}$ & $\mathbf{0}$ & $\mathbf{0}$ & $\mathbf{0}$ \\
\hline $\begin{array}{l}\text { End-Use Appliances for } \\
\text { Refrigeration }\end{array}$ & $\mathbf{0}$ & $\mathbf{0}$ & $\mathbf{0}$ & $\mathbf{0}$ \\
\hline Fan & 1.9 & 67.7 & 4.0 & 0.51 \\
\hline Air condition & 0 & 0 & 0 & 0 \\
\hline $\begin{array}{l}\text { End-Use Appliances for } \\
\text { Ventilation }\end{array}$ & 1.9 & 67.7 & 4.0 & 0.51 \\
\hline TOTAL & 15.8 & 267.4 & 29.6 & 2.22 \\
\hline
\end{tabular}


Average wattage of Power Stabilizer is 45.3, Average hours of usage of Power Stabilizer per Household per day is 7.4, and the Total Power Stabilizer usage is $0.39 \mathrm{KWh} / \mathrm{HH} /$ day. The average number of Phone/ tablet in use per household per day in the estate is 3.7, Average wattage of Phone/ tablet is 9.3, Average hours of usage of Phone/ tablet per Household per day is 4.3 , and the Total Phone/ tablet usage is $0.15 \mathrm{KWh} / \mathrm{HH} /$ day. The average number of Game Console in use per household per day in the estate is 0.2 , Average wattage of Game Console is 18.4, Average hours of usage of Game Console per Household per day is 0.49 , and the Total Game Console usage is $0.05 \mathrm{KWh} / \mathrm{HH} /$ day. There is no usage of UPS, Printers and Solar Calculator in the Estate. The average number of End-Use Appliance for Computing/Internet Services per household per day in the estate is 5.7, Average wattage of End-Use Appliance for Computing/Internet Services is 106.4, Average hours of usage of End-Use Appliance for Computing/Internet Services per Household per day is 14.2, and the Total End-Use Appliance for Computing/Internet Services daily usage is $0.77 \mathrm{KWh} / \mathrm{HH} /$ day. The average number of Radio/Television/Video in use per household per day in the estate is 1.0, Average wattage of Radio/Television/Video is 68.4, Average hours of usage of Radio/Television/Video per Household per day is 2.9, and the Total Radio/Television/Video usage is $0.22 \mathrm{KWh} / \mathrm{HH} /$ day. There is no usage of Musical Instruments in the Estate. The average number of End-Use Appliance for Entertainment Services per household per day in the estate is 1.0, Average wattage of End-Use Appliance for Entertainment Services is 68.4, Average hours of usage of End-Use Appliance for Entertainment Services per Household per day is 2.9, and the Total EndUse Appliance for Entertainment Services daily usage is $0.22 \mathrm{KWh} / \mathrm{HH} /$ day. The average number of Fan in use per household per day in the estate is 1.9, Average wattage of Fan is 67.7, Average hours of usage of Fan per Household per day is 4.0, and the Total Fan usage is $0.51 \mathrm{KWh} / \mathrm{HH} /$ day. There is no usage of Air condition with Solar in the Estate. The average number of End-Use Appliance for Ventilation Services per household per day in the estate is 1.9, Average wattage of End-Use Appliance for Ventilation Services is 67.7, Average hours of usage of End-Use Appliance for Ventilation Services per Household per day is 4.0, and the Total End-Use Appliance for Ventilation Services daily usage is $0.51 \mathrm{KWh} / \mathrm{HH} / \mathrm{day}$. . There is no usage of End-Use appliance for Process Heat, Cooking Services, Water Pumping Services and Refrigeration with Solar in the Estate. The Total daily Solar supply per household for all energy services is $2.22 \mathrm{Kwh} / \mathrm{HH} /$ day, as shown in Table 13.

Table 14 presents the Solar Energy supply for Energy services for Alagbaka Housing Estate (KWh/Household/Day). The table reveals the average number of energy-saving bulbs in use per household per day in the estate is 5.1, Average wattage of energy-saving bulbs is 17.7, Average hours of usage of energy-saving bulbs per Household per day is 6.3, and the Total energy-saving bulbs usage is $0.58 \mathrm{KWh} / \mathrm{HH} /$ day. The average number of Rechargeable Lamps in use per household per day in the estate is 2.1, Average wattage of Rechargeable Lamps is 4.2, Average hours of usage of Rechargeable Lamps per Household per day is 2.5, and the Total Rechargeable Lamps usage is $0.03 \mathrm{KWh} / \mathrm{HH} /$ day. There is no usage of Fluorescent Lamp, Incandescent bulbs, Solar Torch, Solar Lantern, Kerosene Lantern, Gas Lamp, and Candlesticks in the Estate. The average number of End-Use Appliance for Lighting Services per household per day in the estate is 7.2, Average wattage of End-Use Appliance for Lighting Services is 21.9, Average hours of usage of End-Use Appliance for Lighting Services per Household per day is 8.7, and the Total End-Use Appliance for Lighting Services daily usage is $0.62 \mathrm{KWh} / \mathrm{HH} /$ day. The average number of Laptop/ Desktop in use per household per day in the estate is 1.7, Average wattage of Laptop/ Desktop is 74.8, Average hours of usage of Laptop/ Desktop per Household per day is 3.4, and the Total Laptop/ Desktop usage is $0.44 \mathrm{KWh} / \mathrm{HH} /$ day. The average number of Power Stabilizer in use per household per day in the estate is 1, Average wattage of Power Stabilizer is 50, Average hours of usage of Power 
Table 14: Solar PV supply for energy services in Alagbaka Housing Estate

\begin{tabular}{|c|c|c|c|c|}
\hline Energy Services & $\begin{array}{l}\text { Ave. No of Appl. } \\
\text { in use } \\
\text { /Household/day }\end{array}$ & $\begin{array}{l}\text { Appliance } \\
\text { wattage }\end{array}$ & $\begin{array}{l}\text { Ave. usage } \\
\text { hours per } \\
\text { HH per Day }\end{array}$ & $\begin{array}{c}\text { Total Appl. Usage } \\
\text { (KWh/HH/day) }\end{array}$ \\
\hline Energy saving Bulbs & 5.1 & 17.7 & 6.3 & 0.58 \\
\hline Fluorescent Lamps & 0 & 0 & 0 & 0 \\
\hline Incandescent Bulbs & 0 & 0 & 0 & 0 \\
\hline Rechargeable Lamps & 2.1 & 4.2 & 2.5 & 0.03 \\
\hline Solar Touches & 0 & 0 & 0 & 0 \\
\hline Solar Lanterns & 0 & 0 & 0 & 0 \\
\hline Kerosene Lanterns & 0 & 0 & 0 & 0 \\
\hline Gas Lambs & 0 & 0 & 0 & 0 \\
\hline Candle Sticks & 0 & 0 & 0 & 0 \\
\hline $\begin{array}{l}\text { End-Use Appliances for } \\
\text { Lighting Services }\end{array}$ & 7.2 & 21.9 & 8.7 & 0.62 \\
\hline Laptop/desktop & 1.7 & 74.8 & 3.4 & 0.44 \\
\hline Power Stabilizers & 1 & 50 & 6.4 & 0.32 \\
\hline UPS, Printers & 0 & 0 & 0 & 0 \\
\hline Phone/ tablet & 4.0 & 5.8 & 3.4 & 0.08 \\
\hline Solar Calculators & 0 & 0 & 0 & 0 \\
\hline Game Consoles & 0 & 0 & 0 & 0 \\
\hline $\begin{array}{l}\text { End-Use Appliances for } \\
\text { Computing/Internet } \\
\text { Services }\end{array}$ & 6.8 & 130.6 & 13.2 & 0.83 \\
\hline Radio/TV/Videos & 1.1 & 72.9 & 3 & 0.23 \\
\hline Musical Instruments & 0 & 0 & 0 & 0 \\
\hline $\begin{array}{l}\text { End-Use Appliances for } \\
\text { Entertainment Services }\end{array}$ & 1.1 & 72.9 & 3 & 0.23 \\
\hline Shaving Kits & 0 & 0 & 0 & 0 \\
\hline Washing machine & 0 & 0 & 0 & 0 \\
\hline Blender & 0 & 0 & 0 & 0 \\
\hline Iron & 0 & 0 & 0 & 0 \\
\hline $\begin{array}{l}\text { End-Use Appliances for } \\
\text { Process Heat }\end{array}$ & $\mathbf{0}$ & $\mathbf{0}$ & $\mathbf{0}$ & $\mathbf{0}$ \\
\hline Firewood Stove & 0 & 0 & 0 & 0 \\
\hline Kerosene Stove & 0 & 0 & 0 & 0 \\
\hline Improved Firewood Stove & 0 & 0 & 0 & 0 \\
\hline Gas Cooker & 0 & 0 & 0 & - \\
\hline Electric cooker & 0 & 0 & 0 & 0 \\
\hline $\begin{array}{l}\text { End-Use Appliances for } \\
\text { Cooking Services }\end{array}$ & $\mathbf{0}$ & $\mathbf{0}$ & $\mathbf{0}$ & $\mathbf{0}$ \\
\hline $\begin{array}{l}\text { Water Pumping Machine } \\
\text { (Drinking) }\end{array}$ & 0 & 0 & 0 & 0 \\
\hline $\begin{array}{l}\text { Water Pumping Machine } \\
\text { (Irrigation) }\end{array}$ & 0 & 0 & 0 & 0 \\
\hline $\begin{array}{l}\text { End-Use Appliances for } \\
\text { Water Pumping Services }\end{array}$ & $\mathbf{0}$ & $\mathbf{0}$ & $\mathbf{0}$ & $\mathbf{0}$ \\
\hline $\begin{array}{l}\text { End-Use Appliances for } \\
\text { Refrigeration }\end{array}$ & $\mathbf{0}$ & $\mathbf{0}$ & $\mathbf{0}$ & $\mathbf{0}$ \\
\hline Fan & 1 & 70 & 4.0 & 0.28 \\
\hline Air condition & 0 & 0 & 0 & 0 \\
\hline $\begin{array}{l}\text { End-Use Appliances for } \\
\text { Ventilation }\end{array}$ & 1 & 70 & 4.0 & 0.28 \\
\hline TOTAL & 16.1 & 295.4 & 28.9 & 1.96 \\
\hline
\end{tabular}


Stabilizer per Household per day is 6.4, and the Total Power Stabilizer usage is $0.32 \mathrm{KWh} / \mathrm{HH} /$ day. The average number of Phone/ tablet in use per household per day in the Estate is 4.0, Average wattage of Phone/ tablet is 5.8, Average hours of usage of Phone/ tablet per Household per day is 3.4, and the Total Phone/ tablet usage is $0.08 \mathrm{KWh} / \mathrm{HH} /$ day. There is no usage of UPS, Printers, Solar Calculator, and Game console in the Estate. The average number of End-Use Appliance for Computing/Internet Services per household per day in the estate is 6.8, Average wattage of End-Use Appliance for Computing/Internet Services is 130.6, Average hours of usage of End-Use Appliance for Computing/Internet Services per Household per day is 13.2, and the Total End-Use Appliance for Computing/Internet Services daily usage is $0.83 \mathrm{KWh} / \mathrm{HH} /$ day. The average number of Radio/Television/Video in use per household per day in the estate is 1.1, Average wattage of Radio/Television/Video is 72.9, Average hours of usage of Radio/Television/Video per Household per day is 3, and the Total Radio/Television/Video usage is $0.23 \mathrm{KWh} / \mathrm{HH} /$ day. There is no usage of Musical Instruments in the Estate. The average number of End-Use Appliance for Entertainment Services per household per day in the estate is 1.1, Average wattage of End-Use Appliance for Entertainment Services is 72.9, Average hours of usage of End-Use Appliance for Entertainment Services per Household per day is 3, and the Total End-Use Appliance for Entertainment Services daily usage is $0.23 \mathrm{KWh} / \mathrm{HH} /$ day. The average number of Fan in use per household per day in the estate is 1, Average wattage of Fan is 70, Average hours of usage of Fan per Household per day is 4.0, and the Total Fan usage is $0.28 \mathrm{KWh} / \mathrm{HH} /$ day. There is no usage of Air condition with Solar in the Estate. The average number of End-Use Appliance for Ventilation Services per household per day in the estate is 1, Average wattage of End-Use Appliance for Ventilation Services is 70, Average hours of usage of End-Use Appliance for Ventilation Services per Household per day is 4.0, and the Total End-Use Appliance for Ventilation Services daily usage is $0.28 \mathrm{KWh} / \mathrm{HH} /$ day. . There is no usage of End-Use appliance for Process Heat, Cooking Services, Water Pumping Services and Refrigeration with Solar in the Estate. The Total daily Solar supply per household for all energy services is $1.96 \mathrm{Kwh} / \mathrm{HH} / \mathrm{day}$, as shown in Table 14.

Table 15 presents the Solar Energy supply for Energy services for sunshine Housing Estate (KWh/Household/Day). The table reveals the average number of energy-saving bulbs in use per household per day in the estate is 4.4, Average wattage of energy-saving bulbs is 17.7, Average hours of usage of energy-saving bulbs per Household per day is 5.9, and the Total energy-saving bulbs usage is $0.46 \mathrm{KWh} / \mathrm{HH} /$ day. The average number of Rechargeable Lamps in use per household per day in the estate is 2 , Average wattage of Rechargeable Lamps is 5 , Average hours of usage of Rechargeable Lamps per Household per day is 2, and the Total Rechargeable Lamps usage is $0.02 \mathrm{KWh} / \mathrm{HH} /$ day. There is no usage of Fluorescent Lamp, Incandescent bulbs, Solar Torch, Solar Lantern, Kerosene Lantern, Gas Lamp, and Candlesticks in the Estate. The average number of End-Use Appliance for Lighting Services per household per day in the estate is 6.4, Average wattage of End-Use Appliance for Lighting Services is 22.7, Average hours of usage of End-Use Appliance for Lighting Services per Household per day is 7.9, and the Total End-Use Appliance for Lighting Services daily usage is $0.48 \mathrm{KWh} / \mathrm{HH} /$ day. The average number of Laptop/ Desktop in use per household per day in the estate is 2, Average wattage of Laptop/ Desktop is 61.2, Average hours of usage of Laptop/ Desktop per Household per day is 2.9, and the Total Laptop/ Desktop usage is $0.37 \mathrm{KWh} / \mathrm{HH} /$ day. The average number of Power Stabilizer in use per household per day in the estate is 1, Average wattage of Power Stabilizer is 50, Average hours of usage of Power Stabilizer per Household per day is 6, and the Total Power Stabilizer usage is $0.3 \mathrm{KWh} / \mathrm{HH} /$ day. The average number of Phone/ tablet in use per household per day in the estate is 3.9, Average wattage of Phone/ 
tablet is 8, Average hours of usage of Phone/ tablet per Household per day is 3.9, and the Total Phone/ tablet usage is $0.12 \mathrm{KWh} / \mathrm{HH} /$ day. There is no usage of UPS,

Table 15: Solar PV Supply for energy services in Sunshine Housing Estate

\begin{tabular}{|c|c|c|c|c|}
\hline Energy Services & $\begin{array}{c}\text { Ave. No of Appl. in } \\
\text { use } \\
\text { /Household/day }\end{array}$ & $\begin{array}{l}\text { Appliance } \\
\text { wattage }\end{array}$ & $\begin{array}{c}\text { Ave. usage } \\
\text { hours per } \\
\text { HH per Day }\end{array}$ & $\begin{array}{c}\text { Total Appl. Usage } \\
\text { (KWh/HH/day) }\end{array}$ \\
\hline Energy saving Bulbs & 4.4 & 17.7 & 5.9 & 0.46 \\
\hline Fluorescent Lamps & 0 & 0 & 0 & 0 \\
\hline Incandescent Bulbs & 0 & 0 & 0 & 0 \\
\hline Rechargeable Lamps & 2 & 5 & 2 & 0.02 \\
\hline Solar Touches & 0 & 0 & 0 & 0 \\
\hline Solar Lanterns & 0 & 0 & 0 & 0 \\
\hline Kerosene Lanterns & 0 & 0 & 0 & 0 \\
\hline Gas Lambs & 0 & 0 & 0 & 0 \\
\hline Candle Sticks & 0 & 0 & 0 & 0 \\
\hline $\begin{array}{l}\text { End-Use Appliances for } \\
\text { Lighting Services }\end{array}$ & 6.4 & 22.7 & 7.9 & 0.48 \\
\hline Laptop/desktop & 2 & 61.2 & 2.9 & 0.37 \\
\hline Power Stabilizers & 1 & 50 & 6 & 0.3 \\
\hline UPS, Printers & 0 & 0 & 0 & 0 \\
\hline Phone/ tablet & 3.9 & 8 & 3.9 & 0.12 \\
\hline Solar Calculators & 0 & 0 & 0 & 0 \\
\hline Game Consoles & 0 & 0 & 0 & 0 \\
\hline $\begin{array}{l}\text { End-Use Appliances for } \\
\text { Computing/Internet } \\
\text { Services }\end{array}$ & 6.9 & 119.2 & 12.9 & 0.79 \\
\hline Radio/TV/Videos & 1 & 64.7 & 3 & 0.19 \\
\hline Musical Instruments & 0 & 0 & 0 & 0 \\
\hline $\begin{array}{l}\text { End-Use Appliances for } \\
\text { Entertainment Services }\end{array}$ & 1 & 64.7 & 3 & 0.19 \\
\hline Shaving Kits & 0 & 0 & 0 & 0 \\
\hline Washing machine & 0 & 0 & 0 & 0 \\
\hline Blender & 0 & 0 & 0 & 0 \\
\hline Iron & 0 & 0 & 0 & 0 \\
\hline $\begin{array}{l}\text { End-Use Appliances for } \\
\text { Process Heat }\end{array}$ & $\mathbf{0}$ & $\mathbf{0}$ & $\mathbf{0}$ & $\mathbf{0}$ \\
\hline Firewood Stove & 0 & 0 & 0 & 0 \\
\hline Kerosene Stove & 0 & 0 & 0 & 0 \\
\hline Improved Firewood Stove & 0 & 0 & 0 & 0 \\
\hline Gas Cooker & 0 & 0 & 0 & - \\
\hline Electric cooker & 0 & 0 & 0 & 0 \\
\hline $\begin{array}{l}\text { End-Use Appliances for } \\
\text { Cooking Services }\end{array}$ & $\mathbf{0}$ & $\mathbf{0}$ & $\mathbf{0}$ & $\mathbf{0}$ \\
\hline $\begin{array}{l}\text { Water Pumping Machine } \\
\text { (Drinking) }\end{array}$ & 0 & 0 & 0 & 0 \\
\hline $\begin{array}{l}\text { Water Pumping Machine } \\
\text { (Irrigation) }\end{array}$ & 0 & 0 & 0 & 0 \\
\hline $\begin{array}{l}\text { End-Use Appliances for } \\
\text { Water Pumping Services }\end{array}$ & $\mathbf{0}$ & $\mathbf{0}$ & $\mathbf{0}$ & $\mathbf{0}$ \\
\hline $\begin{array}{l}\text { End-Use Appliances for } \\
\text { Refrigeration }\end{array}$ & $\mathbf{0}$ & $\mathbf{0}$ & $\mathbf{0}$ & $\mathbf{0}$ \\
\hline Fan & 1 & 78.8 & 4.0 & 0.32 \\
\hline Air condition & 0 & 0 & 0 & 0 \\
\hline $\begin{array}{l}\text { End-Use Appliances for } \\
\text { Ventilation }\end{array}$ & 1 & 78.8 & 4.0 & 0.32 \\
\hline TOTAL & 15.3 & 285.4 & 27.8 & 1.78 \\
\hline
\end{tabular}


Printers, Solar Calculator, and Game console in the Estate. The average number of End-Use Appliance for Computing/Internet Services per household per day in the estate is 6.9, Average wattage of End-Use Appliance for Computing/Internet Services is 119.2, Average hours of usage of End-Use Appliance for Computing/Internet Services per Household per day is 12.9, and the Total End-Use Appliance for Computing/Internet Services daily usage is $0.79 \mathrm{KWh} / \mathrm{HH} /$ day. The average number of Radio/Television/Video in use per household per day in the estate is 1, Average wattage of Radio/Television/Video is 64.7, Average hours of usage of Radio/Television/Video per Household per day is 3, and the Total Radio/Television/Video usage is $0.19 \mathrm{KWh} / \mathrm{HH} /$ day. There is no usage of Musical Instruments in the Estate. The average number of End-Use Appliance for Entertainment Services per household per day in the estate is 1, Average wattage of End-Use Appliance for Entertainment Services is 64.7, Average hours of usage of End-Use Appliance for Entertainment Services per Household per day is 3, and the Total End-Use Appliance for Entertainment Services daily usage is $0.19 \mathrm{KWh} / \mathrm{HH} /$ day. The average number of Fan in use per household per day in the estate is 1, Average wattage of Fan is 78.8, Average hours of usage of Fan per Household per day is 4.0, and the Total Fan usage is $0.32 \mathrm{KWh} / \mathrm{HH} /$ day. There is no usage of Air condition with Solar in the Estate. The average number of End-Use Appliance for Ventilation Services per household per day in the estate is 1, Average wattage of End-Use Appliance for Ventilation Services is 78.8, Average hours of usage of End-Use Appliance for Ventilation Services per Household per day is 4.0, and the Total End-Use Appliance for Ventilation Services daily usage is $0.32 \mathrm{KWh} / \mathrm{HH} /$ day. . There is no usage of End-Use appliance for Process Heat, Cooking Services, Water Pumping Services and Refrigeration with Solar in the Estate. The Total daily Solar supply per household for all energy services is $1.78 \mathrm{Kwh} / \mathrm{HH} /$ day as shown in Table 15

Table 16 shows that the total daily solar PV supply for each energy services. The total daily solar PV supply per household for lighting energy service is $0.66 \mathrm{Kwh} / \mathrm{HH} /$ day which includes Energy-saving Bulbs $(0.63 \mathrm{Kwh} / \mathrm{HH} /$ day $)$, Incandescent bulbs $(0.001 \mathrm{Kwh} / \mathrm{HH} /$ day $)$ and rechargeable lamps $(0.03 \mathrm{Kwh} / \mathrm{HH} /$ day). The total daily solar PV supply per household for computing/internet services is $0.79 \mathrm{Kwh} / \mathrm{HH} /$ day which comprises of laptop at $0.31 \mathrm{Kwh} / \mathrm{HH} /$ day, power stabilizer $0.36 \mathrm{Kwh} / \mathrm{HH} /$ day, phones/tablet $0.13 \mathrm{Kwh} / \mathrm{HH} /$ day and game consoles $0.05 \mathrm{Kwh} / \mathrm{HH} /$ day. The total daily solar PV supply per household for entertainment services is $0.22 \mathrm{Kwh} / \mathrm{HH} /$ day, which comprises of Radio/TV/Videos. The total daily solar PV supply per household for Process heat services, cooking, water pumping and refrigeration is $0 \mathrm{Kwh} / \mathrm{HH} /$ day. The total daily solar PV supply per household for ventilation services is $0.42 \mathrm{Kwh} / \mathrm{HH} /$ day. This is shown in Table 16 
Table 16: Solar PV Demand for energy services

\begin{tabular}{|c|c|c|c|c|}
\hline Energy Services & $\begin{array}{l}\text { Ave. No of Appl. } \\
\text { in use } \\
\text { /Household/day }\end{array}$ & $\begin{array}{l}\text { Appliance } \\
\text { wattage }\end{array}$ & $\begin{array}{c}\text { Ave. usage } \\
\text { hours per HH } \\
\text { per Day }\end{array}$ & $\begin{array}{c}\text { Total Appl. Usage } \\
\text { (KWh/HH/day) }\end{array}$ \\
\hline Energy saving Bulbs & 5.3 & 18.6 & 6.3 & 0.63 \\
\hline Fluorescent Lamps & 0 & 0 & 0 & 0 \\
\hline Incandescent Bulbs & 0.005 & 0.3 & 0.01 & 0.001 \\
\hline Rechargeable Lamps & 1.8 & 4.9 & 2.1 & 0.03 \\
\hline Solar Touches & 0 & 0 & 0 & 0 \\
\hline Solar Lanterns & 0 & 0 & 0 & 0 \\
\hline Kerosene Lanterns & 0 & 0 & 0 & 0 \\
\hline Gas Lambs & 0 & 0 & 0 & 0 \\
\hline Candle Sticks & 0 & 0 & 0 & 0 \\
\hline $\begin{array}{l}\text { End-Use Appliances for } \\
\text { Lighting Services }\end{array}$ & 7.1 & 23.8 & 8.5 & 0.66 \\
\hline Laptop/desktop & 1.4 & 60 & 2.8 & 0.31 \\
\hline Power Stabilizers & 1 & 47 & 7 & 0.36 \\
\hline UPS, Printers & 0 & 0 & 0 & 0 \\
\hline Phone/ tablet & 3.8 & 8.1 & 4 & 0.13 \\
\hline Solar Calculators & 0 & 0 & 0 & 0 \\
\hline Game Consoles & 0.2 & 18.4 & 0.49 & 0.05 \\
\hline $\begin{array}{l}\text { End-Use Appliances for } \\
\text { Computing/Internet } \\
\text { Services }\end{array}$ & 6.4 & 115 & 14 & 0.79 \\
\hline Radio/TV/Videos & 1 & 69 & 3 & 0.22 \\
\hline Musical Instruments & 0 & 0 & 0 & 0 \\
\hline $\begin{array}{l}\text { End-Use Appliances for } \\
\text { Entertainment Services }\end{array}$ & 1 & 69 & 3 & 0.22 \\
\hline Shaving Kits & 0 & 0 & 0 & 0 \\
\hline Washing machine & 0 & 0 & 0 & 0 \\
\hline Blender & 0 & 0 & 0 & 0 \\
\hline Iron & 0 & 0 & 0 & 0 \\
\hline $\begin{array}{l}\text { End-Use Appliances for } \\
\text { Process Heat }\end{array}$ & $\mathbf{0}$ & $\mathbf{0}$ & $\mathbf{0}$ & $\mathbf{0}$ \\
\hline Firewood Stove & 0 & 0 & 0 & 0 \\
\hline Kerosene Stove & 0 & 0 & 0 & 0 \\
\hline Improved Firewood Stove & 0 & 0 & 0 & 0 \\
\hline Gas Cooker & 0 & 0 & 0 & - \\
\hline Electric cooker & 0 & 0 & 0 & 0 \\
\hline $\begin{array}{l}\text { End-Use Appliances for } \\
\text { Cooking Services }\end{array}$ & $\mathbf{0}$ & $\mathbf{0}$ & $\mathbf{0}$ & $\mathbf{0}$ \\
\hline $\begin{array}{l}\text { Water Pumping Machine } \\
\text { (Drinking) }\end{array}$ & 0 & 0 & 0 & 0 \\
\hline $\begin{array}{l}\text { Water Pumping Machine } \\
\text { (Irrigation) }\end{array}$ & 0 & 0 & 0 & 0 \\
\hline $\begin{array}{l}\text { End-Use Appliances for } \\
\text { Water Pumping Services }\end{array}$ & $\mathbf{0}$ & $\mathbf{0}$ & $\mathbf{0}$ & $\mathbf{0}$ \\
\hline $\begin{array}{l}\text { End-Use Appliances for } \\
\text { Refrigeration }\end{array}$ & $\mathbf{0}$ & $\mathbf{0}$ & $\mathbf{0}$ & $\mathbf{0}$ \\
\hline Fan & 1.5 & 70 & 4 & 0.42 \\
\hline Air condition & 0 & 0 & 0 & 0 \\
\hline $\begin{array}{l}\text { End-Use Appliances for } \\
\text { Ventilation }\end{array}$ & 1.5 & 70 & 4 & 0.42 \\
\hline TOTAL & 16 & 277.8 & 29.5 & 2.09 \\
\hline
\end{tabular}


Table 17 shows that in Ijapo Housing Estate, share of PV in Lighting services is 27.9\%, Computing/internet services is $57.3 \%$, Entertainment Services is $18.3 \%$, Process heat Services is $0 \%$, Cooking Services is $0 \%$, Water pumping Services is $0 \%$, Refrigeration services is $0 \%$, and Ventilation services is $16.8 \%$. The Total share of PV for energy services in Ijapo Housing Estate is $8.8 \%$. In Alagbaka Housing Estate share of PV in Lighting services is 26.5\%, Computing/internet services are $70.6 \%$, Entertainment Services is $13.7 \%$, Process heat Services is $0 \%$, Cooking Services is $0 \%$, Water pumping Services is $0 \%$, Refrigeration services are $0 \%$, and Ventilation services are $4.4 \%$. The Total share of PV for energy services in Alagbaka Housing Estate is 6.7\%. In Sunshine Housing Estate share of PV in Lighting services is $24.0 \%$, Computing/internet services are $50 \%$, Entertainment Services is $14.1 \%$, Process heat Services is $0 \%$, Cooking Services is 0\%, Water pumping Services is $0 \%$, Refrigeration services are $0 \%$, and Ventilation services are $1.8 \%$. The Total share of PV for energy services in Ijapo Housing Estate is $4.4 \%$. The Overall share of PV in Lighting services is $27.2 \%$, Computing/internet services are $59.6 \%$, Entertainment Services is $16.3 \%$, Process heat Services is $0 \%$, Cooking Services is $0 \%$, Water pumping Services is $0 \%$, Refrigeration services are $0 \%$, and Ventilation services are $6.9 \%$. The overall share of PV for energy services is $7.33 \%$, as shown in Table 17, which is lower than the proposed $18 \%$ target set by the renewable energy master plan in 2005.

Table 17: Share of solar PV contribution in the study area

\begin{tabular}{|c|c|c|c|c|c|c|c|c|c|c|c|c|}
\hline \multirow[b]{2}{*}{$\begin{array}{l}\text { Energy } \\
\text { Services }\end{array}$} & \multicolumn{3}{|c|}{ Ijapo Housing Estate } & \multicolumn{3}{|c|}{ Alagbaka Housing Estate } & \multicolumn{3}{|c|}{ Sunshine Housing Estate } & \multicolumn{3}{|l|}{ Total } \\
\hline & $\begin{array}{c}\text { Share } \\
\text { of PV } \\
\text { (Kwh) }\end{array}$ & $\begin{array}{c}\text { Total } \\
\text { Demand } \\
\text { (KWh) }\end{array}$ & $\begin{array}{c}\text { Percentage } \\
\%\end{array}$ & $\begin{array}{c}\text { Share } \\
\text { of PV } \\
\text { (Kwh) }\end{array}$ & $\begin{array}{c}\text { Total } \\
\text { Demand } \\
\text { (KWh) }\end{array}$ & $\begin{array}{c}\text { Percentage } \\
\%\end{array}$ & $\begin{array}{c}\text { Share } \\
\text { of PV } \\
\text { (Kwh) }\end{array}$ & $\begin{array}{c}\text { Total } \\
\text { Demand } \\
\text { (KWh) }\end{array}$ & $\begin{array}{c}\text { Percentage } \\
\%\end{array}$ & $\begin{array}{c}\text { Share } \\
\text { of PV } \\
\text { (Kwh) }\end{array}$ & $\begin{array}{c}\text { Total } \\
\text { Demand } \\
\text { (KWh) }\end{array}$ & $\begin{array}{c}\text { Percentage } \\
\%\end{array}$ \\
\hline $\begin{array}{l}\text { Lighting } \\
\text { services }\end{array}$ & 92.4 & 331 & 27.9 & 36.3 & 137 & 26.5 & 15.4 & 64.1 & 24.0 & 144.1 & 529.76 & $27.2 \%$ \\
\hline $\begin{array}{l}\text { Computing / } \\
\text { internet } \\
\text { services }\end{array}$ & 98.8 & 172.4 & 57.3 & 49.1 & 69.5 & 70.6 & 25.4 & 50.8 & 50 & 173.3 & 290.67 & $59.63 \%$ \\
\hline $\begin{array}{l}\text { Entertainment } \\
\text { Services }\end{array}$ & 28.5 & 155.8 & 18.3 & 13.7 & 99.8 & 13.7 & 6.23 & 44.2 & 14.1 & 48.4 & 297.03 & $16.30 \%$ \\
\hline $\begin{array}{l}\text { Process heat } \\
\text { Services }\end{array}$ & 0 & 93.9 & 0 & 0 & 37.8 & 0 & 0 & 19.7 & 0 & 0 & 150.65 & $0 \%$ \\
\hline $\begin{array}{l}\text { Cooking } \\
\text { Services }\end{array}$ & 0 & 701.5 & 0 & 0 & 360 & 0 & 0 & 10.1 & 0 & 0 & 1061.6 & $0 \%$ \\
\hline $\begin{array}{l}\text { Water } \\
\text { pumping } \\
\text { Services }\end{array}$ & 0 & 54.2 & 0 & 0 & 5.2 & 0 & 0 & 4.2 & 0 & 0 & 63.58 & $0 \%$ \\
\hline $\begin{array}{l}\text { Refrigeration } \\
\text { services }\end{array}$ & 0 & 1343.5 & 0 & 0 & 649.2 & 0 & 0 & 539.8 & 0 & 0 & 2520.50 & $0 \%$ \\
\hline $\begin{array}{l}\text { Ventilation } \\
\text { services }\end{array}$ & 65.1 & 387 & 16.8 & 16.5 & 373.7 & 4.4 & 10.1 & 567.2 & 1.8 & 91.7 & 1326.16 & $6.9 \%$ \\
\hline Total & 284.8 & 3239.3 & 8.8 & 115.6 & 1732.2 & 6.7 & 57.1 & 1300.2 & 4.4 & 457.6 & 6240 & $7.33 \%$ \\
\hline
\end{tabular}

Researcher's Field Report (2019)

\section{CONCLUSION}

The study concludes that the Status of Solar PV is working well although the current contribution of solar PV in energy demand split for the estates was still very low, with with a total share of $8.8 \%, 6.7 \%$ and $4.4 \%$ in Ijapo, Alagbaka and Sunshine Housing Estate despite various government interventions. Its usage level constituted an insignificant share of $27.9 \%$, $57.3 \%, 18.3 \%, 0 \%, 0 \%, 0 \%, 0 \%$, and $16.8 \%$ for the total lighting, computing/internet, 
entertainment, process heat, cooking, refrigeration, water pumping and ventilation services requirement respectively in Ijapo Housing Estate, 26.5\%, 70.6\%, 13.7\%, 0\%, 0\%, 0\%, 0\%, and $16.5 \%$ for the total lighting, computing/internet, entertainment, process heat, cooking, refrigeration, water pumping and ventilation services requirement respectively in Alagbaka Housing Estate, and 24.0\%, 50\%, 14.1\%,0\%, 0\%, 0\%, 0\%, and 1.8\% for the total lighting, computing/internet, entertainment, process heat, cooking, refrigeration, water pumping and ventilation services requirement respectively in Sunshine Housing Estate. PV utilization is currently limited to lighting services, computing/internet, entertainment, and ventilation services, whereas its high potentials for other services need to be explored. Also, food and vaccine preservation through refrigeration, ventilation and water pumping for provision of potable water and farm irrigation are yet to be fully harnessed.

Based on the findings from the study, the following are recommended

1. Government support for solar PV intervention in these Estates should be further encouraged.

2. Solar PV Usage for lighting, entertainment and computing services by the Estates is commendable and an increase in the intensity of usage essential.

3. Its usage for food and vaccine preservation through refrigeration; ventilation and water pumping for provision of potable water and farm irrigation should also be researched.

Funding: This research received no external funding.

Conflicts of Interest: Declare conflicts of interest or state "The authors declare no conflict of interest."

\section{References}

UNDP (2015): Sustainable Development Goals (SDGs). Retrieved 05:28, March 11, 2019, from http://www.undp.org/content/undp/en/home/mdgoverview/post-2015-development-agenda.html\&nbsp

Stevance, Anne-Sophie, Dave Griggs, Måns Nilsson, \& David McCollum. (2017): A GUIDE TO SDG INTERACTIONS: FROM SCIENCE TO IMPLEMENTATION'. International Council for Science (ICSU).

https://www.icsu.org/cms/2017/05/SDGs-Guide-to-Interactions.pdf. Chapter on SDG 7 (p. 127-173) includes linkages between SDG7 and other SDGs.

Bazilian, M., Nussbaumer, P., Eibs-Singer, C., Brew-Hammond, A., Modi, V., Sovacool, B., Ramana, V. \& Aqrawi, P. K. (2012) Improving Access to Modern Energy Services: Insights from Case Studies. Electr. J, 25, pp93-114

Pachauri, S., van Ruijven, B. J., Nagai, Y., Riahi, K., van Vuuren, D. P., Brew-Hammond, A. \& Nakicenovic, N. (2013):

Pathways to achieve universal household access to modern energy by 2030. Environ. Res. Lett, 8, 24015

Groh, S. (2014): The role of energy in development processes - the energy poverty penalty: Case study of Arequipa (Peru). Energy Sustainable Development

Ulsrud, K., Winther, T., Palit, D. \& Rohracher, H. (2015): Village-level solar power in Africa: Accelerating access to electricity services through a socio-technical design in Kenya. Energy Res. Soc. Sci. 2015, 5, 34-44

Emovon I, Samuel, O. D., Mgbemena, C. O., Adeyeri, M. K., 2018: Electric Power generation crisis in Nigeria: A review of causes and solution. International Journal of Intergrated Engineering Vol.10 p 47-56

Jesuleye, O.A. (2010): Analysis of Solar Photovoltaics Utilization in Selected Rural Areas of Nigeria, Ph.D. dissertation, Technology Planning and Development Unit, Obafemi Awolowo University, Ile-Ife.

ECN \& UNDP. (2005): Nigeria Renewable Energy Master Plan (REMP); Retrieved March, 2019 www.areanet.org/fileadmin/user uploada/AREA/AREA downloads/AREA_Conferene_09/Presentations/Nigeria Renewable Energy Masterplan.pdf

Akinwale, Y, and Adepoju A. (2019): Factors influencing willingness to adopt renewable energy technologies among micro and small enterprises in Lagos State Nigeria, International Journal of Sustainable Energy Planning and Management, Vol. 19 pages 69-82 
Onasanya, M. A. (2010): Optimised Utilization of Renewable Energy Resources in Nigeria. International Conference on Environmental Issue (ICE2), April 18-20

Holladay, A. (2006): Solar Energy, Microsoft Student 2007. Redmond WA: Microsoft Corporation.

Wikipedia, (2019): Federal University of Technology Akure, Akure

Devine-Wright, P. (2017): Reconsidering public attitudes and public acceptance of renewable energy technologies: a critical review. School of Environment and Development, University of Manchester, Oxford Road, Manchester M13 9PL, UK, 2007. http://geography.exeter.ac.uk/beyond_nimbyism/deliverables/bn_wp1_4.pdf (Accessed 11 march 2019)

Huijts, N., Molin, E. and Steg, L. (2011): Psychological factors influencing sustainable energy technology acceptance: A review-based comprehensive framework. Renewable Energy and Sustainable Energy Reviews, 16 pp 525-531. https://doi.org/10.1016/j.rser.2011.08.018

Lan, Z. and Li, J. (2014): Photovoltaic technology and electricity saving strategies for fixedvelocity- measuring system. TELKOMNIKA Indones J Electr Eng, 12 (6) 4419-4426

Silveira, J. L., Tuna, C. E. and Lamas, W. Q. (2013): The need of subsidy for the implementation of photovoltaic solar energy as supporting of decentralized electrical power generation in Brazil. Renewable Sustainable Energy Review, 20, 133-141

REN21, (2018): Renewable global status report 2018 update. Renewable Energy Policy Network for the 21st century.

Jesuleye, O.A. (2010): Solar PV demand for lighting in Nigerian remote villages International Journal of Management and Applied Science, ISSN: 2394-7926 Volume-3, Issue-10, Oct.-2017 http://iraj.in

Ismail, O. S., Ajide, O. O., \& Akingbesote, F. (2012): Performance Assessment of Installed Solar PV System: A Case Study of Oke-Agunla in Nigeria. Engineering, 4(08), 453. https://doi:10.4236/eng.2012.48059

Melodi, A. O. and Famakin, S. R. (2011): Assessment of Solar PV-Grid Parity Akure, South-West Nigeria. Journal of Emerging trend in Engineering and Applied Sciences (JETAS, 2 (3), 531-536

Cooper, D. R, \& Schindler, P.S (2003): Business Research Meethods. UK: Oxford University Press.

Mugenda, O. M, \& Mugenda, A. G. (2003): Research Methods: Quantitative and Qualitative Approaches. Nairobi: African Centre for technology Studies

Asiyanbola, R. A (2005): Patriarchy, Male Dominance, the Role and Women in Nigeria. Paper Submitted for presentation as poster at the international Union for scientific Study of population (IUSSP/UIESP) XXV International Population Tours, France, 18-23 https://www.semanticsscholar.org/paper/patriarchy-\%2C-maledominance-\%2C-the-role-and-women-in-Asiyanbola/cca9d9aabdb150739fb73f8a22ae9f7392bd8eb7

Olaniyan, K, Mclellan, B.,Ogata, S., \& Tezuka, T. (2018): Estimating Residential Energy Consumption in Nigeria to Support Energy Transitions. Sustainability. https://doi.org/10.3390/su10051440

Fakere, A. A (2017): Effects of Levels of Residents' Participation in House Design on Residential Satisfaction in Public Housing Estates in Akure, Nigeria. Covenant Journal of Research in the Built Environment. 5 (1). 